\title{
TRICHOPTERA (INSECTA) COLLECTED IN MEDITERRANEAN RIVER BASINS OF THE IBERIAN PENINSULA: TAXONOMIC REMARKS AND NOTES ON ECOLOGY
}

\author{
N. Bonada*, C. Zamora-Muñoz**, M. Rieradevall* and N. Prat*
}

\begin{abstract}
As a result of the GUADALMED project, undertaken in Iberian Mediterranean basins, to which were added samples taken by the junior author in the area, we collected numerous caddisfly larvae, pupae and adults. Some larvae were also reared in the lab to obtain adults and allow proper identification. A total of 90 species were identified, which accounts for more than a fourth of the species known in the Iberian Peninsula and Balearic Islands. Here we confirm the presence of doubtful species in the Iberian Peninsula (Glyphotaelius pellucidus) and we expand the distribution range of others (Lype reducta, Micrasema minimum, Limnephilus guadarramicus, Sericostoma pyrenaicum). Moreover, because of the unconformity of morphological larval characteristics with present taxonomical keys (Mesophylax aspersus) or lack of larvae descriptions (Allogamus mortoni, Stenophylax espanioli), here we include some relevant taxonomical aspects that are useful to identify larvae. A brief description of the larva of a possible new species of Hydropsyche (from now on $H$. gr. instabilis) is also given.
\end{abstract}

Key words: Trichoptera, Mediterranean rivers, Iberian Peninsula, Faunistics, Taxonomy, Ecology.

\section{RESUMEN}

Los tricópteros (Insecta) recolectados en las cuencas mediterráneas de la Península Ibérica: notas taxonómicas y requerimientos ecológicos

Como resultado de los estudios realizados en el proyecto GUADALMED en las cuencas de los ríos mediterráneos peninsulares y otros muestreos realizados por la primera autora del trabajo se han recolectado numerosas larvas, pupas y adultos de tricópteros. Algunas larvas fueron criadas en el laboratorio para la obtención de adultos y con ello asegurar su identificación. Se han identificado un total de 90 especies que suponen más de una cuarta parte de las especies actualmente conocidas en la Península Ibérica y Baleares. En este trabajo se confirma la presencia, hasta ahora dudosa en la Península Ibérica, de algunas especies (Glyphotaelius pelluci$d u s$ ) y se amplia el área de distribución de otras (Lype reducta, Micrasema minimum, Limnephilus guadarramicus, Sericostoma pyrenaicum). Además, se incluyen algunos aspectos taxonómicos relevantes para la identificación de algunas larvas en futuros estudios, debido a que las claves ya existentes no describen correctamente la larva (Mesophylax aspersus) o porque se trata de larvas sin describir (Allogamus mortoni, Stenophylax espanioli). Se añade también una somera descripción de la larva de una posible nueva especie de Hydropsyche (citada aquí como $H$. gr. instabilis) y que requiere un estudio más detallado.

Palabras clave: Trichoptera, ríos Mediterráneos, Península Ibérica, Faunística, Taxonomía, Ecología.

* Department of Ecology, University of Barcelona, Diagonal, 645. E-08028 Barcelona (Spain).

** Department of Animal Biology and Ecology, University of Granada, Campus Universitario de Fuentenueva. E-18071 Granada (Spain). 


\section{Introduction}

Studies on caddisflies in the Iberian Peninsula date from the mid-nineteenth century; although most have been performed recently (González et al., 1992). Most taxonomic research has been done in northern and central areas of Spain (García de Jalón, 1982; González et al., 1987), although contributions from southern regions are increasing (e.g. Ruiz et $a l ., 2001)$ and new species have recently been described (González \& Ruiz, 2001; Zamora-Muñoz et al., 2002). Along the Mediterranean coast of the Iberian Peninsula, taxonomic and faunistic (see examples in González et al., 1992; Malicky, 2002) but also ecological studies have been performed on many caddisfly species (Puig et al., 1981; Herranz \& García de Jalón, 1984; Gallardo-Mayenco, 1993; Gallardo-Mayenco et al., 1998), but no extensive studies have been performed until now.

In the Iberian Peninsula, the Order Trichoptera comprises numerous species with 390 records although only 325 species can be identified with confidence (see updated checklist of Trichoptera from the Iberian Peninsula by González, 2003). The Iberian Peninsula hosts more caddisfly species than other parts of Europe (e.g. England, with 207 species; Edington \& Hildrew, 1995; Wallace et al., 1990), but has similar numbers to other Mediterranean Basin countries (e.g. Italy, with 381 species - Cianficconi, 2002).

Here we present a list of 90 caddisfly species after identification of 12,499 larvae, 177 pupae and 261 adults collected during a survey of 15 river basins located along the Mediterranean coast of the Iberian Peninsula.

\section{Materials and methods}

Trichoptera were collected mainly from 10 basins situated along the Mediterranean coast of the Iberian Peninsula and selected from the GUADALMED Project (Fig. 1): Besòs, Llobregat, Mijares, Turia, Júcar, Segura, Almanzora, Aguas, Adra and Guadalfeo (a description of the basins sampled can be found in Robles et al., 2002). Moreover, we also include data obtained from several ecological studies of the Foix, Tordera, Ter, Noguera Ribagorçana and Guadalquivir basins (Prat et al., 1999, 2000 and 2001; Rieradevall \& Prat, 2000; Solà, 2001) (Fig. 1). Overall, the study area lies whitin the mediterranean climate zone (Köppen, 1923), with annual precipitation ranging from less than $300 \mathrm{~mm}$ in the more arid basins of the southeast to over $800 \mathrm{~mm}$ in northern basins and in some mountain areas. The basins are formed by limestone and sedimentary materials, although some siliceous areas are also present, such as in the Sierra Nevada, Pyrenees and Montseny ranges. The vegetation in the basins mainly consists of sclerophyllous and evergreen trees and shrubs, although in the more mountainous areas deciduous and coniferous forests are present. As in other mediterranean climate regions, the basins have been greatly affected by human activity (Trabaud, 1981), such as agriculture, cattle farming, urbanization, salinization, water utilization and regulation (Conacher \& Sala, 1998). All these factors have negatively affected the rivers, either directly or indirectly (Prat \& Ward, 1994).

Caddisfly larvae and pupae were obtained by sampling all available habitats with a kick net of $250 \mathrm{~mm}$ mesh size. They were then preserved in formalin (4\%) or alcohol (70\%) before identification to maximum taxonomic level in the lab. Larvae and pupae were also collected in the field, transported to the lab and reared to obtain pupae and adults, using a similar method as in VieiraLanero (1996). This system consists of a tank with a constant water temperature of $19^{\circ} \mathrm{C}$. A water pump recirculated and cleaned the water in a closed circuit, exposed it to natural light, and simultaneously provided oxygen. Pupae and larvae from last instars were located in small circular plastic cages and were separated by sampling sites or rivers. Each cage had a substrate composed of clean gravel. For shredders, leaf-litter was taken from riverbeds. For grazers, stones with periphyton were collected at the same site where larvae were obtained. We did not rear larvae of predators or filter-feeders

In addition, adults were also obtained in the field by sweeping riparian vegetation with an entomological net or using a light trap with a UV-light connected to a car battery. To identify adults and pupae, genitalia were digested in a $10 \% \mathrm{KOH}$ solution, at a constant temperature of $90^{\circ} \mathrm{C}$. Once digested, they were placed in a glycerin solution and were observed and identified under a stereoscope or microscope.

\section{Results}

A total of 12,499 larvae, 177 pupae and 261 adults from 169 sites were identified. We present Trichoptera species following the taxonomical 


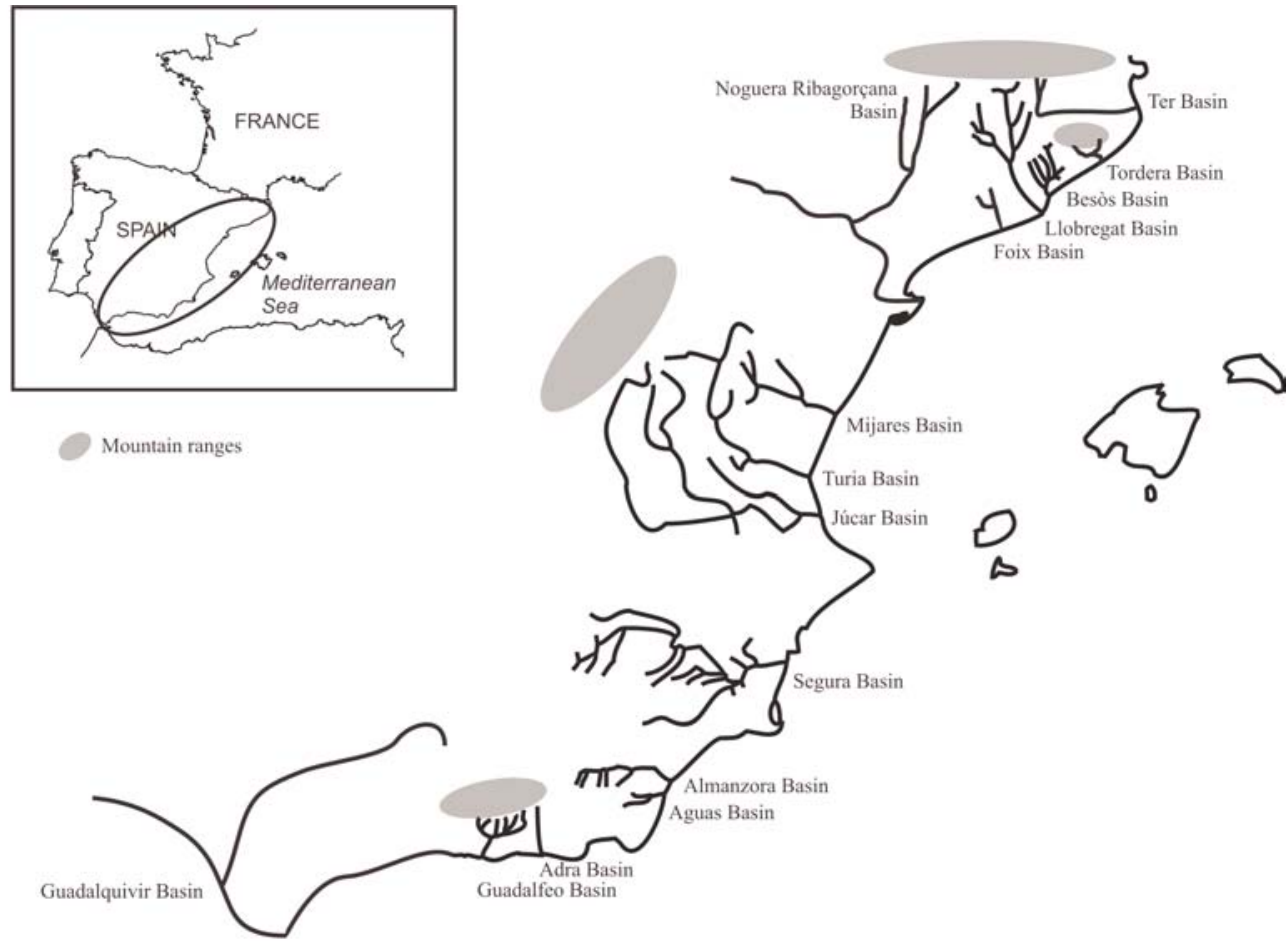

Fig. 1.- Basins sampled along Mediterranean coast of Iberian Peninsula.

Fig. 1.-Cuencas muestreadas en la costa Mediterránea de la Peninsula Ibérica.

classification described by Wiggins (1996). We omitted subgenera because they are not widely used in the literature (Vieira-Lanero, 2000). For each species, the number of larvae (L), pupae (P) and adults $\left(\mathrm{O}^{\top}\right.$ and $Q$ ) are given. In general, only the identification of male specimens is included. Females were identified only when they appeared with several males (e.g. in Agapetus), or when they belonged to families where females are quite well known (e.g. Limnephilidae). For pupae and adults, the sampling months are shown in brackets. Capture sites were classified by basin, and coded by a letter and a number. Their exact location is presented in the Appendix. In some cases, a question mark (?) is added before some sampling localities when the identity of the larvae found was not clear.

When thought necessary, some taxonomic remarks are presented, including information about subspecies or morphological characteristics. Table 1 includes information about ecology and the general and local distribution of each species collected, based on our study and the literature.
Suborder SPICIPALPIA

Family RHYACOPHILIDAE Stephens, 1836

Subfamily Rhyacophilinae Stephens, 1836

Rhyacophila Pictet, 1834

Rhyacophila dorsalis (Curtis, 1834)

MATERIAL STUdied: 324L, 10Pơ $0^{\top} 3 \mathrm{P}$ 우 $ᄋ$ (IV, V, VII, VIII), $30^{7} \sigma^{7}$ (IV, V). Ter Basin: T3, T4, T8, T10; Tordera Basin: ToM8, ToM12; Besòs Basin: B25, B32; Llobregat Basin: L38, L42, L54, L56, L57, L60a, L60c, L61, L68, L77; Mijares Basin: MI4; Turia Basin: TU1, TU2, TU4, TU6, TU9; Júcar Basin: JU8

The males collected in the Llobregat River corresponded to the "Pyrenee form" (Malicky, pers. com., 2001); however, because the taxonomic situation of $R$. dorsalis in these mountains is still unclear, the subspecies of this form is not given (Malicky, 2002).

\section{Rhyacophila evoluta McLachlan, 1879}

Material StUdied: 43L, 1Po (V), $3 \sigma^{x} \sigma^{x}$ (VII). Ter basin: T1, T2, T8, T9, T10, T11 


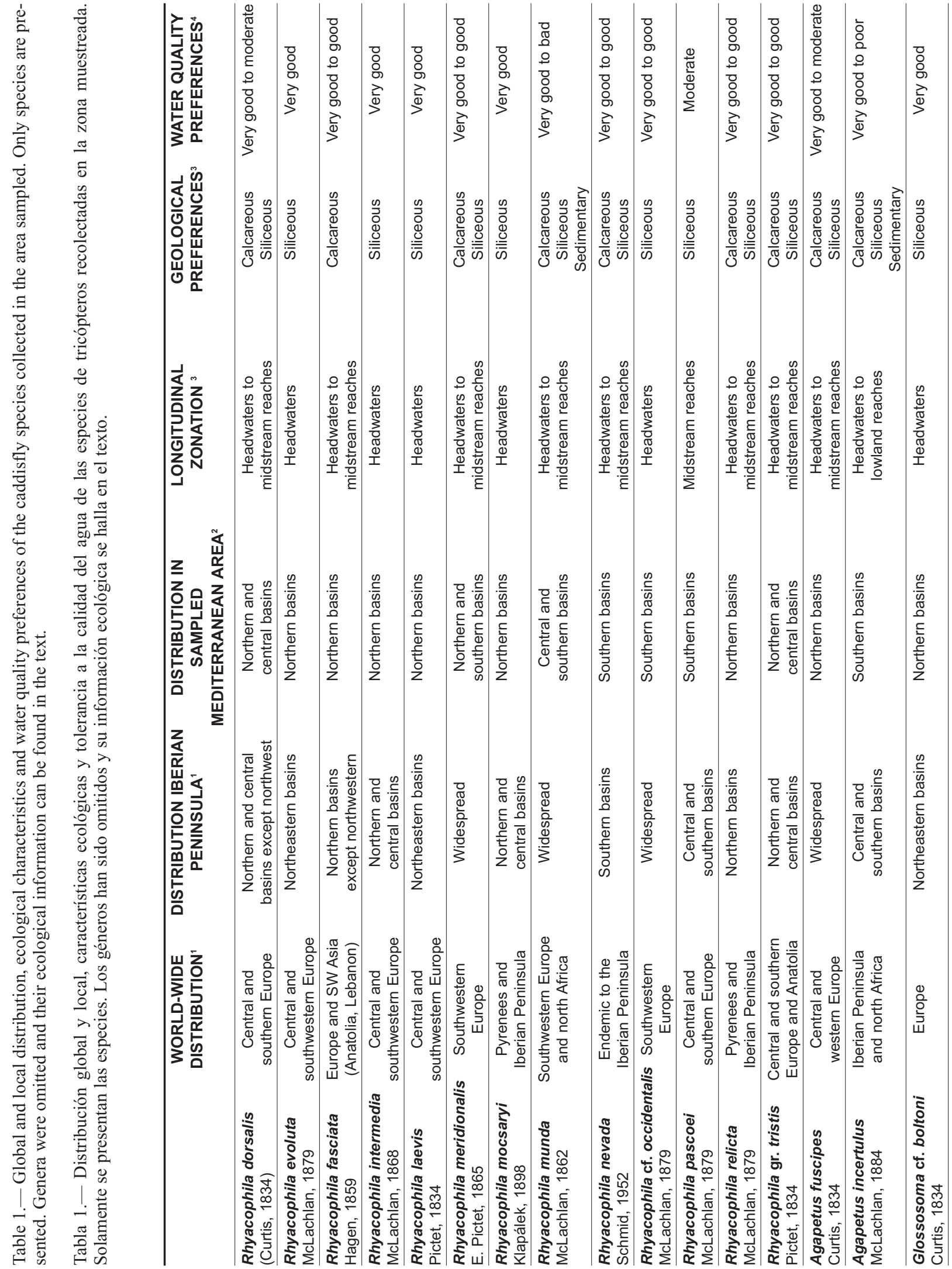




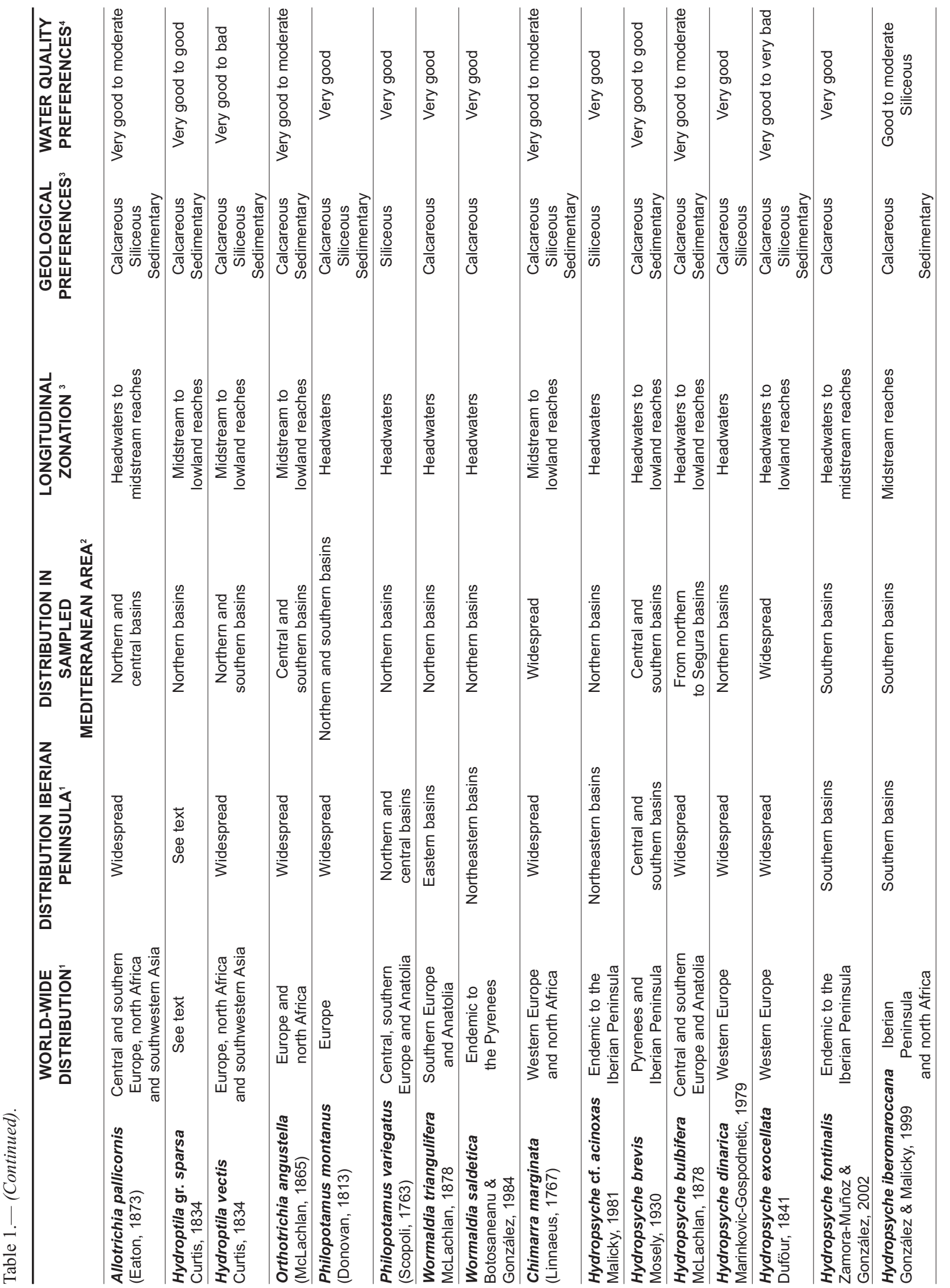




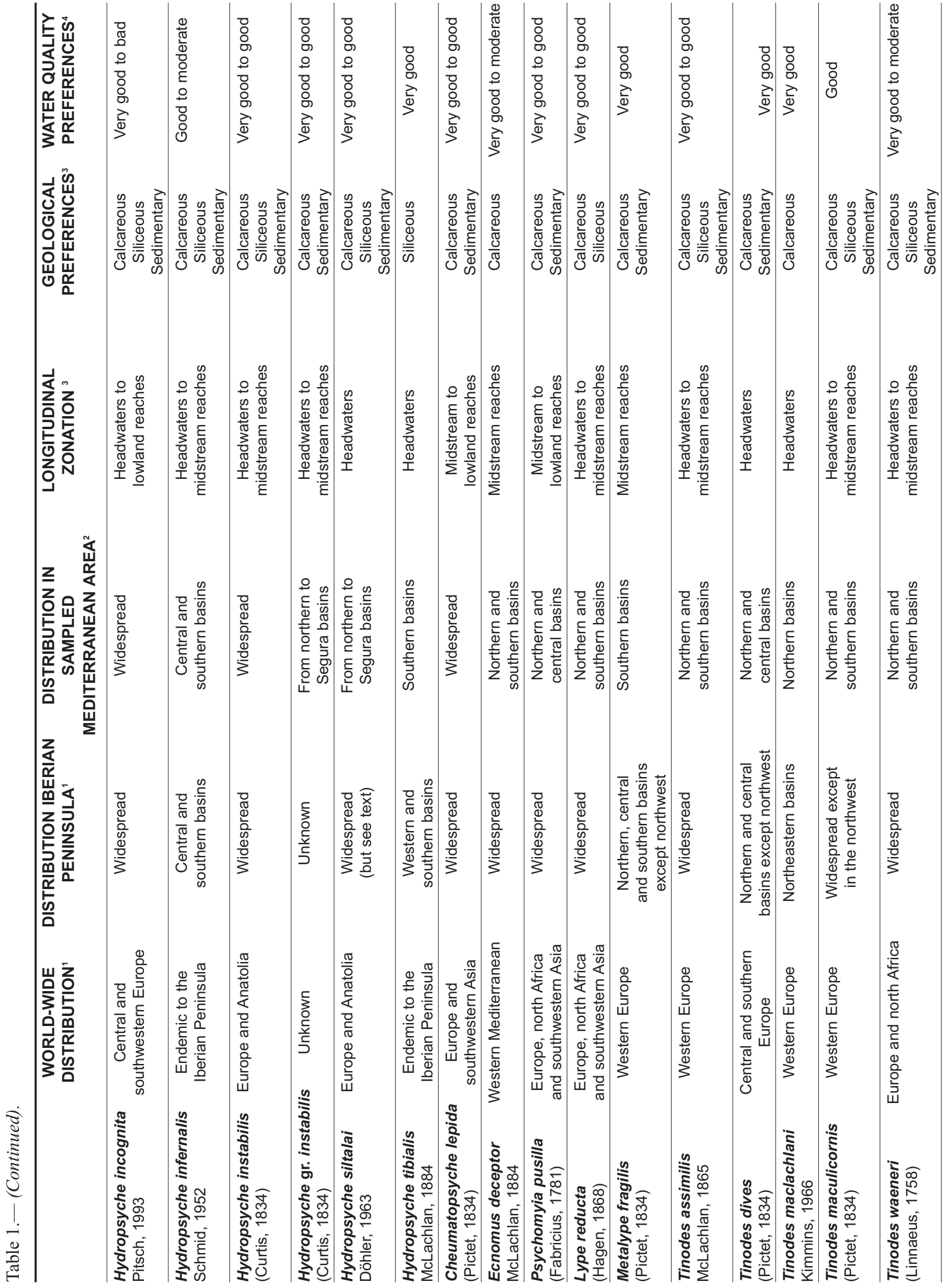




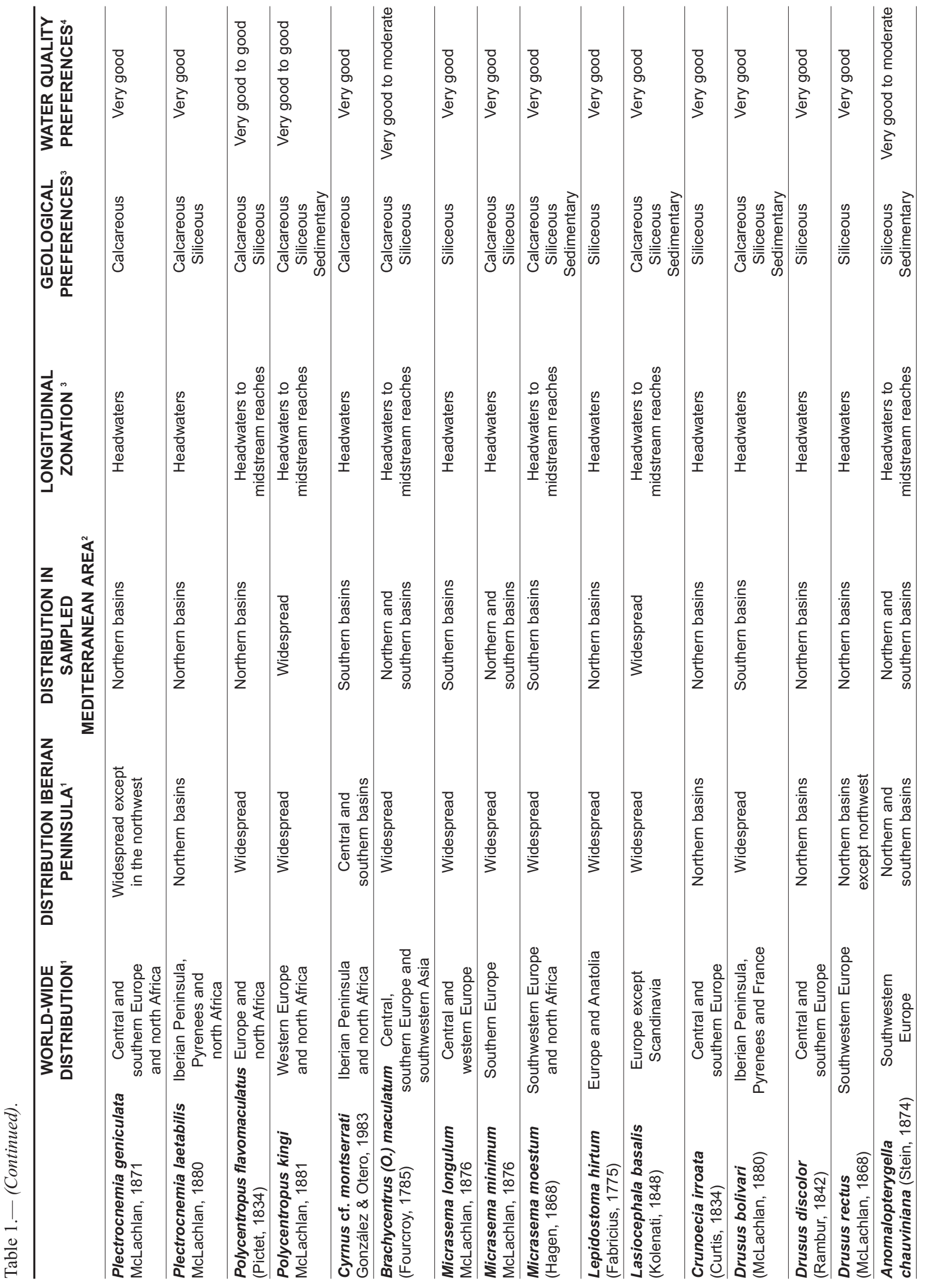




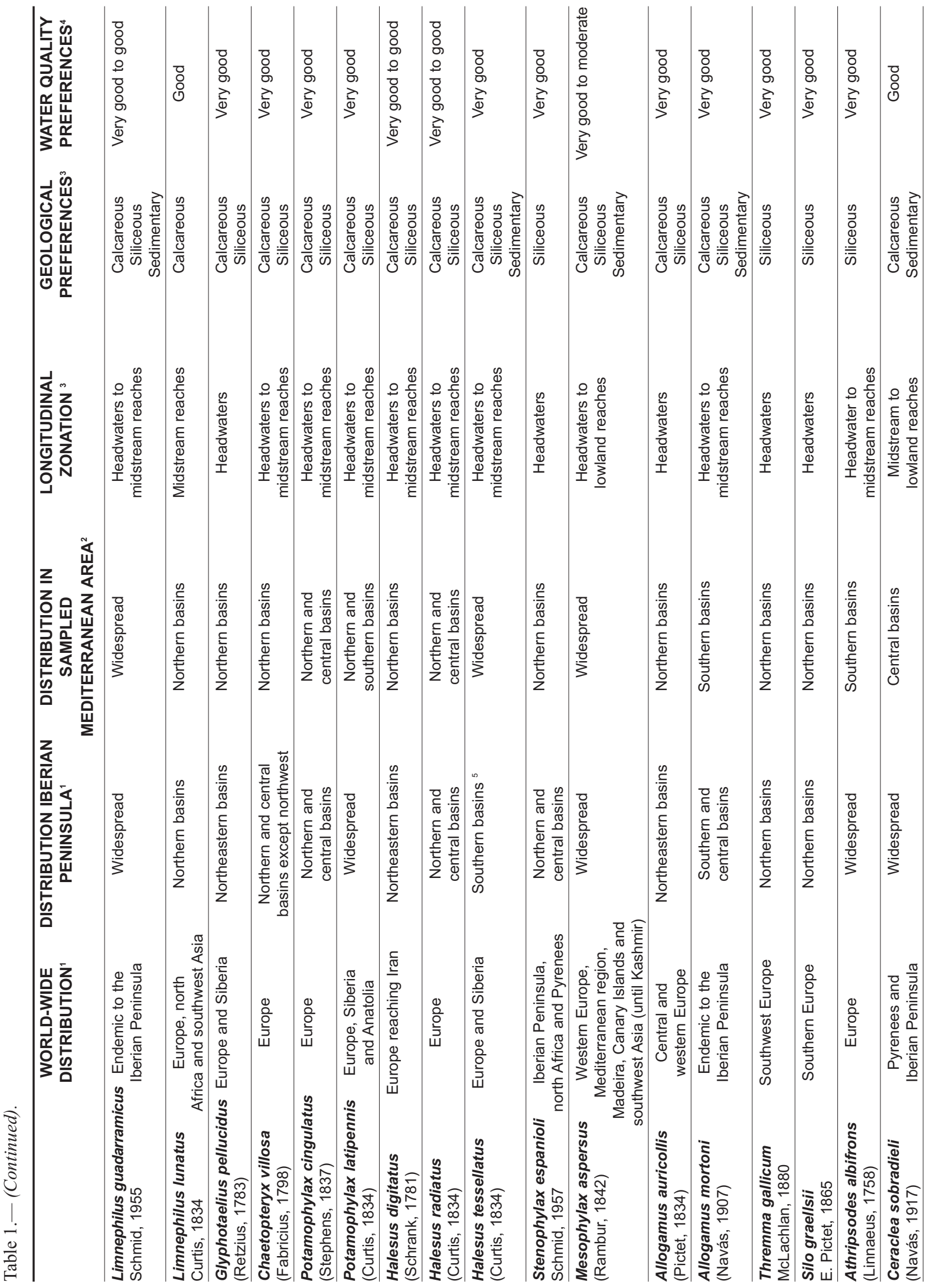




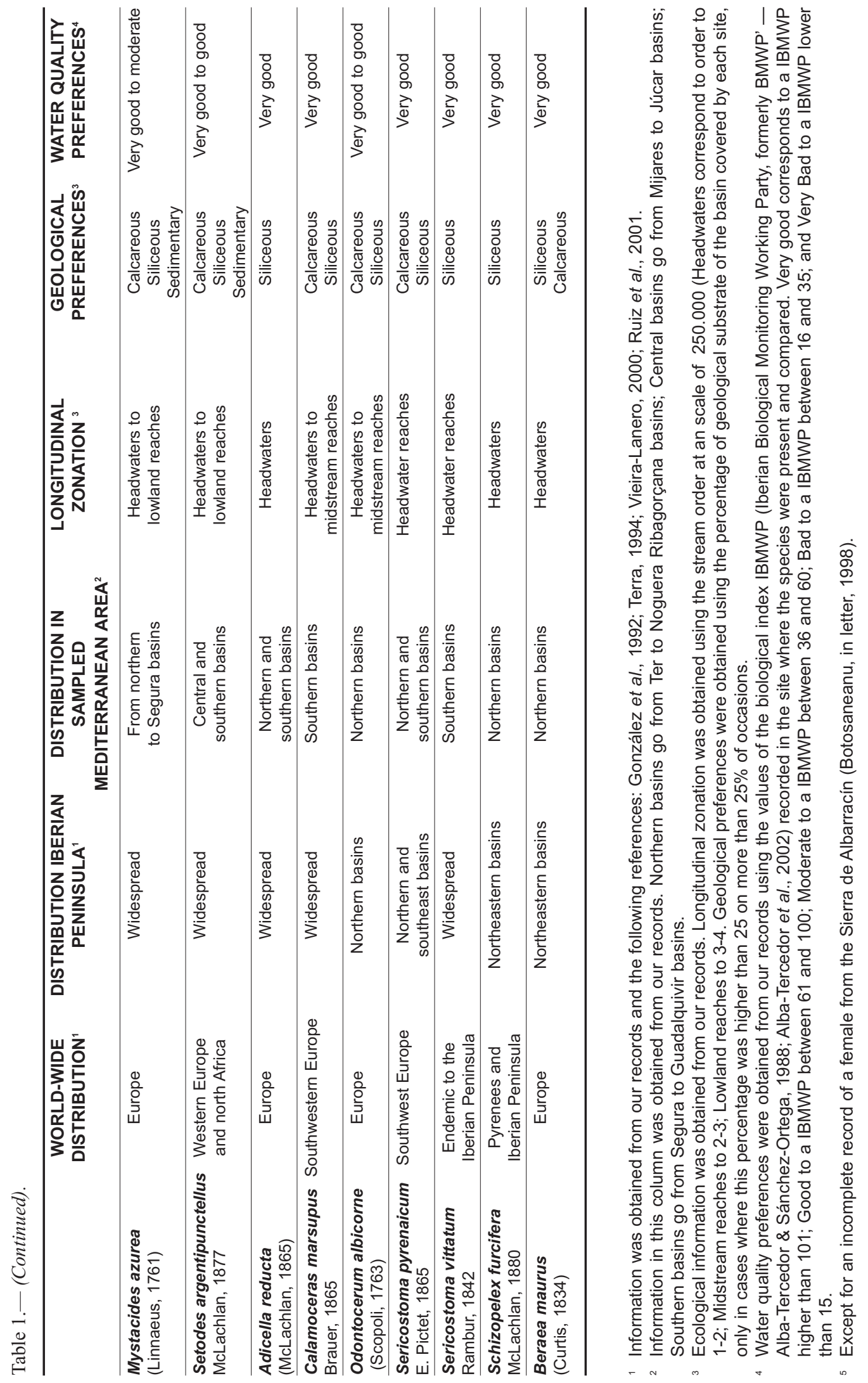


Although $R$. evoluta was formerly cited in the midstream reaches of the Llobregat River (Puig et al., 1981), the revision of the original material (from the Barcelona University collection) and the new samples from the same sites do not show the presence of this species in this area. Therefore, all previous records of $R$. evoluta from the Llobregat River belong to $R$. dorsalis and the data from Puig et al. (1981) must be referred to this species.

\section{Rhyacophila fasciata Hagen, 1859}

Material Studied: ?3L, 2Pơ $0^{\pi}$ (IV, VII). Ter Basin: T10; Llobregat Basin: L43, L60a

There is some controversy regarding $R$. fasciata and $R$. denticulata. Malicky \& Sipahiler (1993) consider $R$. denticulata as a subspecies of $R$. fasciata, in spite of its distinct larva (Vieira-Lanero, 2000), whose sword process differs in length (but see Basaguren, 1990; Zamora-Muñoz \& AlbaTercedor, 1992). On the other hand, while González et al. (1992) and González (2003) consider R. denticulata as a different species, they state that the presence of $R$. fasciata in the Iberian Peninsula should be confirmed.

We identified the pupae found in the Llobregat River (L60a) as R. fasciata denticulata, and the sclerites in the pupal cocoon presented a long sword process, which does not correspond to the larval description of $R$. denticulata (Despax, 1928). Moreover, some larvae collected in the Ter and Llobregat rivers presented the typical morphology of $R$. fasciata, with a long sword process and an apotome with a black posterior patch with black muscle insertions (according to Buholzer, 1978; Waringer \& Graf, 1997). A specific study analyzing adults of $R$. fasciata denticulata and the variability of their larvae should be performed to determine whether $R$. denticulata is a subspecies of $R$. fasciata, and thus to confirm the presence of $R$. fasciata in the Iberian Peninsula.

Rhyacophila intermedia McLachlan, 1868

Material StUdied: 2L, $1 \sigma^{\pi}$ (VII). Noguera Ribagorçana Basin: OUT0m, INLET

\section{Rhyacophila laevis Pictet, 1834}

Material StUdied: 2L. Noguera Ribagorçana Basin: OUT200m, INLET

\section{Rhyacophila meridionalis E. Pictet, 1865}

Material studied: 150L, 2Po $\sigma^{7}$ (VIII), $1 \sigma^{\pi}$ (X). Ter Basin: T9, T10, T12, TM2, TM5; Tordera Basin: ToM5, ToM6, ToM8, ToM10, ToM12, ToM13, ToM15; Besòs Basin: B32; Llobregat
Basin: L54, L56; Segura Basin: SE01; Almanzora Basin: AL6; Adra Basin: AD5; Guadalfeo Basin: GU1, GU5, GU11, GU15

The colour pattern of the head of $R$. meridionalis larva is very variable (Décamps, 1965; VieiraLanero, 2000). In our study area, we have found the two forms described by Zamora-Muñoz et al. (1997). Most of the specimens collected in northern basins (i.e., Ter, Tordera, Besòs and Llobregat) were similar to those in northwestern Spain (Vieira-Lanero, 2000), which is consistent with the original description made by Décamps (1965). In contrast, the larvae found in southern basins (Segura, Almanzora, Adra and Guadalfeo) were similar to the colour pattern described in Zamora-Muñoz et al. (1997).

\section{Rhyacophila mocsaryi Klapálek, 1898}

Material StUdied: 37L. Ter basin: T3, T4, T7, T8, T10, TM4, TM5

In the Iberian Peninsula and Pyrenees this species is associated with the subspecies tredosensis (González et al., 1992).

\section{Rhyacophila munda McLachlan, 1862}

MAterial STUdied: 141L, 4Po' ơ 3P ㅇ ㅇ (I, IV, VII), 1 ㅇ (V). Mijares Basin: MI7; Turia Basin: TU12; Júcar Basin: JU5, JU9, JU12, JU13, JU19; Segura Basin: SE1, SE3, SE4, SE5, SE7, SE16; Almanzora Basin: AL2, AL6, AL10, AL11; Aguas Basin: AG1; Adra Basin: AD2, AD3, AD4; Guadalfeo Basin: GU4, GU5, GU6, GU7, GU8, GU9, GU10, GU11, GU12, GU13, GU14, GU15, GU16

The length of the sword process can be used to distinguish the larva of $R$. munda from other species of the Pararhyacophila-group; this process being shorter in $R$. munda (Viedma \& García de Jalón, 1980). However, Malicky \& Lounaci (1987) pointed out that an error in the original description of $R$. munda by Edington \& Hildrew (1981) may have occurred, implying that $R$. munda may also present a long sword process. In this regard, we found that the specimens of $R$. munda from the south and southeast of the Iberian Peninsula always showed a longer process than that expected. All the specimens collected in Adra, Guadalfeo, Mijares, Turia, Júcar, Segura, Almanzora and Aguas basins presented a long sword process and a spherical protuberance on the posteroventral area of the protrochanter, characters that differ from the description of this species from Iberian material (Viedma \& García de Jalón, 1980) and which are also discussed in Vieira-Lanero et al. (2001). We encountered some difficulties when applying published keys to identify larval specimens, although we classified them as $R$. munda. 
This species is widely distributed and very abundant in southern Spain and although more pupae and adults are needed to confirm larval identifications, in some of the basins studied, the rearing of larvae in the lab confirmed their identity in the Adra and Guadalfeo basins, as in other nearby basins (e.g. Genil and Guadiana Menor basins; Zamora-Muñoz, 1992; Picazo-Muñoz, 1995).

The larva of $R$. munda shows a strong similarity to the undescribed $R$. fonticola, which is also present in southern Spain and coexists at some sites (Ruiz et al., 2001). Because $R$. fonticola is still undescribed we classified all the specimens collected as $R$. munda.

\section{Rhyacophila nevada Schmid, 1952}

Material studied: 160L, 6Po $\sigma^{7}$ (II, IV, VII, X), $1 \sigma^{7}$ (VII). Almanzora Basin: AL6, AL7; Segura Basin: SE1, SE3, SE4, SE8; Adra Basin: AD4; Guadalfeo Basin: GU1, GU2, GU3, GU4, GU5, GU6, GU7, GU9, GU10, GU11, GU12, GU13, GU14, GU15

Recently, after analyzing a few imagines, Malicky (2002) considered $R$. nevada a sub-species of $R$. dorsalis. However, according to Zamora-Muñoz \& AlbaTercedor (1992), these two species have distinctly different larvae, which are differentiated by size and colour patterns of head and pronotum. $R$. dorsalis cephalic pleurae show an inconspicuous pattern of dark spots, present on $R$. nevada, and a continuous shade pattern of the pronotum on the posterior half (Figs. 2a and 2b). Except in a few larvae, the head patterns of the specimens collected in northern basins, where only $R$. dorsalis was present, fitted well with Zamora-Muñoz's step-key corresponding to $R$. dorsalis. On the other hand, in southern basins, most of the specimens corresponded to $R$. nevada, and a few had typical features of $R$. dorsalis. Therefore, our material confirms that larvae of $R$. dorsalis and $R$. nevada can be distinguished along the Mediterranean coast of the Iberian Peninsula.

Rhyacophila nevada displayed an ecological profile which differed greatly from that of $R$. dorsalis. $R$. nevada shows preferential distribution in pristine headwaters with predominant siliceous basins, and was more sensitive to water pollution than $R$. dorsalis. Consequently, because of the differences observed in larval morphology and ecology of these two species, and because of the few specimens analyzed by Malicky, here we consider them as distinct species.

Rhyacophila cf. occidentalis McLachlan, 1879

Material Studied: 24L. Adra Basin: AD5; Guadalfeo Basin: GU1, GU11, GU15
Larvae from the Adra and Guadalfeo basins were similar to those of $R$. occidentalis. However, we did not find any mature pupae or adults to confirm the identity of the species.

\section{Rhyacophila pascoei McLachlan, 1879}

Material StUdied: 1L. Guadalfeo Basin: GU16

Rhyacophila relicta McLachlan, 1879

Material StUdied: 39L. Ter Basin: T10, T12; Tordera Basin: ToM9; Llobregat Basin: L42, L54, L64, L68, L60a, L67

\section{Rhyacophila gr. tristis Pictet, 1834}

Material StUdied: 102L, $60^{7} \sigma^{7}$ (V, VII, VIII). Ter Basin: T2, T3, T5, T8, T10, T11, TM4, TM5; Tordera Basin: ToM13; Besòs Basin: B32; Llobregat Basin: L44, L45, L54, L56, L60a; Noguera Ribagorçana Basin: OUT0m, OUT200m, INLET; Júcar Basin: JU7

We found one imago in the Mongrony River (NE Spain, Pyrenees), which presented several taxonomic features similar to those of $R$. aquitani$c a$, cited by Navás in nearby areas, a species that requires confirmation in the Iberian Peninsula (see González et al., 1992). However, we consider our specimen to be $R$. gr. tristis because of the absence of characters to differentiate the males of these two species with certainty and the high variability in $R$. tristis (González, pers. com., 2001). Similarly, it was difficult to distinguish the larvae of $R$. tristis from those of $R$. aquitanica. Buholzer (1978) observed that $R$. tristis does not present ventral transversal stripes in the cephalic capsule, whereas $R$. aquitanica does. In northwestern Spain, where only $R$. tristis has been found, the larva has such transversal stripes (Vieira-Lanero, pers. com., 2001), as is also the case in our specimens. Consequently, we considered both larvae and adult to belong to $R$. gr. tristis.

Family GLOSSOSOMATIDAE Wallengren, 1891
Subfamily Agapetinae Martynov, 1913

Agapetus Curtis, 1834

This genus is abundant and widely distributed in the Mediterranean, but the larvae of several species have not been described to date (e.g. A. theischingeri, A. incertulus - but see Ruiz et al., in press). We found many larvae of this genus, but because of the uncertainties in its identification, we present only the species confirmed by pupae or adults. It is interesting to point out that the Agapetus specimens found in southern basins were more tolerant to 
pollution than expected from literature (González del Tánago \& García de Jalón, 1984), especially with regard to suspended solids, conductivity, nitrites and ammonium. This tolerance could indicate the presence of one or several undescribed species.

Agapetus fuscipes Curtis, 1834

Material Studied: 8Po $0^{7} 0^{7} 3 \mathrm{P}$ ㅇ ㅇ (II, IV, V, VII), $10^{7}$ (V). Ter Basin: T3, T10; Besòs Basin: B12, B35; Llobregat Basin: L82; Foix Basin: F24

Vieira-Lanero (2000) found that most of the larvae of $A$. fuscipes collected in northwest Spain lacked lateral setae in the third abdominal segment. In our case, larvae collected where A. fuscipes pupae were found presented the typical seta pattern of $A$. fuscipes of 2-1-1 (first, second and third lateral setae of abdominal segments).

Agapetus incertulus McLachlan, 1884

Material Studied: 1Pơ (VII), $30^{7} 0^{7}$ (V, VII). Segura Basin: SE16; Adra Basin: AD3, AD1

Although this species appears to be widespread in the Iberian Peninsula according to the literature (see González et al., 1992; Ruiz et al., in press), the records in north Spain (Vizcaya region) seem to be an error. Checking the original source of the Vizcaya record (García de Jalón, 1982), A. incertulus was only recorded in Guadalajara and Jaén (central and southern Spain). The species of Agapetus recorded in Vizcaya to date are $A$. delicatulus, $A$. fuscipes and A. ochripes (Basaguren, 1990).

\section{Synagapetus McLachlan, 1879}

This genus was found in the Ter, Tordera and Besòs basins and coexisted with Agapetus. However, because many larvae still remain undescribed and we did not collect pupae or adults, we were unable to identify larvae at species level.

Subfamily Glossosomatinae Wallengren, 1891

Glossosoma Curtis, 1834

Glossosoma cf. boltoni Curtis, 1834

Material StUdied: 22L. Ter Basin: T1, T2, T7, T8, T9, T10, T11

The larvae in our samples resembled G. boltoni, but we did not collect mature pupae to ensure larval identifications. From the species of the Glossosoma genus, the larva of G. spoliatum McLachlan, 1879 remains undescribed. $G$. boltoni has been cited in north and northeast Spain (González et al., 1992), where G. spoliatum is also present.

\author{
Family HYDROPTILIDAE Stephens, 1836 \\ Subfamily Hydroptilinae Stephens, 1836 \\ TRIBUS Hydroptilini Stephens, 1836
}

Allotrichia McLachlan, 1880

Allotrichia pallicornis (Eaton, 1873)

Material studied: 36L. Besòs Basin: B35; Mijares: MI8; Júcar Basin: JU11

Although we did not collect pupae or adults, our larvae fit the redescription done by Vieira-Lanero (2000), and showed a dorsal sclerite at the IX abdominal segment.

\section{Hydroptila Dalman, 1819}

Given the fact that the larvae of several species distributed along the Mediterranean coast of the Iberian Peninsula remain undescribed (of 31 species recorded in the Peninsula, only the larvae of 6 are known - Vieira-Lanero, 2000), and the difficulties to distinguish those already described, here we present only the results obtained from pupae and adults.

\section{Hydroptila gr. sparsa Curtis, 1834}

Material STUdied: 1Pơ (VIII). Llobregat Basin: L68

The sparsa-group is highly variable (Malicky, 1997) and is distributed throughout Europe, north Africa and southwest Asia. Our specimen resembled $H$. angustata, which is recorded only in the southern basins of the Iberian Peninsula.

\section{Hydroptila vectis Curtis, 1834}

Material StUdied: $8 \mathrm{P} \circ^{7} \sigma^{\top} 2 \mathrm{P}$ 우 (II, IV, V, VIII, IX), $260^{7} 0^{\top} 10$ 우 우 (II, VIII, XI). Tordera Basin: ToM9; Llobregat Basin: L60a, L61, L68; Foix Basin: F25; Almanzora Basin: AL4; Adra Basin: AD1, AD4; Guadalfeo Basin: GU6, GU7, GU9

\section{Oxyethira Eaton, 1873}

This genus comprises five species in the Iberian Peninsula, and it is difficult to identify their larvae (see Vieira-Lanero, 2000). Specimens from this genus were collected in reaches of the Segura, Aguas and Almanzora basins at altitudes between 
210 and $920 \mathrm{~m}$. Given that we did not find pupae or adults, we could not identify our specimens.

TRIBUS Orthotrichiini Nielsen, 1948

Ithytrichia Eaton, 1873

The larvae of this genus were found in midstream reaches of the Turia, Júcar and Segura basins, but because of the lack of pupae or adults and the little information available on larval stages (with some species undescribed or difficult to differentiate -Vieira-Lanero, 2000), we were unable to identify the material collected.

Orthotrichia Eaton, 1873

Orthotrichia angustella (McLachlan, 1865)

Material Studied: 30L. Júcar Basin: JU2, JU6, JU8, JU9, JU13; Segura Basin: SE18

Suborder ANNULIPALPIA

Superfamily PHILOPOTAMOIDEA Stephens, 1829

Family PHILOPOTAMIDAE Stephens, 1829

Subfamily Philopotaminae Stephens, 1829

Philopotamus Stephens, 1829

Philopotamus montanus (Donovan, 1813)

Material STUdied: 344L, 3P $\sigma^{7} \sigma^{7} 1 \mathrm{P}$ \% (IV, VII, VIII) $250^{\circ} \sigma^{7}$ (III, IV, V). Ter Basin: T1, T2, T4, T7, T10, T14, T15, T16, TM2, TM5; Tordera Basin: ToM12, ToM13, ToM14, ToM15; Besòs Basin: B35; Llobregat Basin: L56; Noguera Ribagorçana Basin: OUT0m; Segura Basin: SE4; Adra: AD5; Guadalfeo Basin: GU1, GU5, GU11

Philopotamus variegatus (Scopoli, 1763)

Material Studied: $2 \sigma^{7} \sigma^{\pi}$ (V, VI). Ter Basin: T3, T17

\section{Wormaldia McLachlan, 1865}

The difficulty to distinguish larvae, and even adults, of this genus is notable. Therefore, although larval specimens from the same genus were found in the Tordera, Besòs, Turia and Júcar basins, only adult records are presented.

\section{Wormaldia triangulifera McLachlan, 1878}

Material StUdied: $10^{7}$ (IV). Llobregat Basin: L45

The specimen found belonged to the triangulife$\mathrm{ra}$ sub-species, which is distributed in south-west Europe (González et al., 1992).
Wormaldia saldetica Botosaneanu \& González, 1984

MATERIAL STUDIED: 1Pơ (II). Llobregat Basin: SC1

Subfamily Chimarrinae Rambur, 1842

Chimarra Stephens, 1829

Chimarra marginata (Linnaeus, 1767)

Material StUdied: 786L, 1Po (X), $2 \sigma^{7} \sigma^{7}$ (V, VIII). Llobregat Basin: L42, L44, L45, L60a, L61; Mijares Basin: MI5 MI6, MI9; Turia Basin: TU10, TU12; Júcar Basin: JU2, JU3, JU4, JU8, JU13, JU15, JU17, JU19; Segura Basin: SE5; Almanzora Basin: AL14, AL15; Aguas Basin: AG1, AG2, AG7; Adra Basin: AD3; Guadalfeo Basin: GU7, GU9

Superfamily HYDROPSYCHOIDEA Curtis, 1835 Family HYDROPSYCHIDAE Curtis, 1835 Subfamily Hydropsychinae Curtis, 1835

Hydropsyche Pictet, 1834

Hydropsyche cf. acinoxas Malicky, 1981

Material StUdied: 4Pơ $\sigma^{x}$ (IV, VIII). Tordera Basin: ToM7, ToM8, ToM12; Besòs Basin: B8a

The pupae found fit quite well under H. acinoxas, although there were slight differences in the X segment, which were difficult to evaluate (González, pers. com., 2001). The larvae collected and sclerites found from pupae could be confused with larvae and sclerites of H. dinarica and H. ambigua (Fig. 2c and Zamora-Muñoz et al., 1995, for comparison). However, the apotome was less wide and pentagonal than $H$. dinarica and not as rounded in its lateral edges than in H. ambigua. In the dark colouration of the apotome only three light indistinct spots can be distinguished: two on the epistomal sulcus and one on the oral area (Fig. 2c). The apotome of $\mathrm{H}$. cf. acinoxas lacks any light aboral spots, as in H. ambigua.

The holotype of $H$. acinoxas was found in Ter basin at $1000 \mathrm{~m}$ of altitude by Malicky (1981), and it has been recorded also in the Montseny ranges (Filbà, 1986). Our pupae were found in small rivers in the Montseny ranges.

\section{Hydropsyche brevis Mosely, 1930}

Material StUdied: 58L. Mijares Basin: MI5, MI6, MI9; Turia Basin: TU9, TU10; Júcar Basin: JU2, JU4, JU5, JU12, JU13, JU17; Segura Basin: SE5, SE8, SE18

Hydropsyche bulbifera McLachlan, 1878

Material STUdied: 47L, 1Pơ (VII). Besòs Basin: B22; Llobregat Basin: L44, L45; Mijares Basin: MI3, MI4, MI10; Segura Basin: SE1, SE2, SE5 
Hydropsyche dinarica Marinkovic-Gospodnetic, 1979

Material StUdied: 980L, 1Pơ (VII), $2 \sigma^{7} \sigma^{7}$ (VII). Ter Basin: T2, T7, T8, T10, TM2. TM4, TM5; Tordera Basin: ToM15; Llobregat Basin: L56, L54

\section{Hydropsyche exocellata Duföur, 1841}

Material StUdied: 3372L, 3Po $0^{x}$ (IV, VIII), $30^{x} 0^{x}$ (IV). Besòs Basin: B10, B12, B16, B17a, B22, B25, B30, B35; Llobregat Basin: L38, L39, L42, L56, L60a, L60c, L64a, L68, L90, L91, L94, L95, L100, L101, L102; Mijares Basin: MI1, MI3, MI6, MI8; Turia Basin: TU6, TU7, TU8, TU9, TU10, TU11, TU13; Júcar Basin: JU2, JU3, JU4, JU5, JU9, JU10, JU11, JU12, JU13, JU15, JU16, JU17, JU19; Segura Basin: SE6, SE10; Almanzora Basin: AL7; Adra Basin: AD1; Guadalfeo Basin: GU9, GU10.

Although this species has been found mainly in midstream and lowland reaches (e.g. García de Jalón, 1986; Usseglio-Polatera, 1992) we found a few individuals in some headwater reaches with very good water quality.

Hydropsyche fontinalis Zamora-Muñoz \& González, 2002 Material STUdied: 2L. Segura Basin: SE4

Hydropsyche iberomaroccana González \& Malicky, 1999

Material studied: 13L, $10^{7}$ (IV). Adra Basin: AD3; Guadalfeo Basin: GU7, GU9

Larvae identified as $H$. iberomaroccana followed the distinctive head pattern reported by Zamora-Muñoz et al. (1995) (=H. cf. punica). We collected $H$. iberomaroccana only in southern areas, although it was difficult to distinguish its larvae from those of $H$. incognita. However, characteristic $H$. iberomaroccana larvae (like those divided in step 17 by Zamora-Muñoz et al., 1995) were not found in northern basins.

\section{Hydropsyche incognita Pitsch, 1993}

Because of the difficulty in distinguishing larvae of $H$. incognita from those of $H$. iberomaroccana, both species found in the Iberian Mediterranean area (Zamora-Muñoz et al., 1995), only the records from pupae or adults of the former are presented. We also collected 1,677 larvae that we identified as $H$. gr. pellucidula.

Material studied: 14P $\sigma^{\pi} \sigma^{\pi}$ (II, IV, VII, VIII, X), $9 \sigma^{7} \sigma^{\pi}$ (II, IV, V, IX). Llobregat Basin: L44, L60c; Foix Basin: F25; Almanzora Basin: AL14; Aguas Basin: AG2, AG3, AG5; Adra Basin: AD2; Guadalfeo Basin: GU8, GU9

Recently, all the specimens recorded as $H$. pellucidula (Curtis, 1834) in the Iberian Peninsula have been classified as $H$. incognita because there is no evidence of the presence of $H$. pellucidula in the area (Malicky, pers. com., in Vieira-Lanero, 2000).

\section{Hydropsyche infernalis Schmid, 1952}

Material STUdiEd: 115L. Turia Basin: ?AF1; Segura Basin: SE3, SE7, SE16; Almanzora Basin: AL1, AL6, AL14; Aguas Basin: AG1, AG2; Adra Basin: AD3, AD4, AD5; Guadalfeo Basin: GU2, GU4, GU5, GU6, GU12, GU13

No pupae or adults were collected, but larvae displayed a V-shape aboral spot in the apotome, as described in Zamora-Muñoz et al. (1995) (Fig. 2d). In northwestern Spain (where $H$. infernalis has not been recorded - Vieira-Lanero, 2000), $H$. siltalai (a close species that also lacks gills on the 7th abdominal segment) has an apotome similar to $H$. infernalis with a V-shaped aboral spot (VieiraLanero, 2000), instead of the typical U-shaped spot (Edington \& Hildrew, 1995; Zamora-Muñoz et al., 1995). Therefore, in areas where these two species may coexist, it may be difficult to distinguish larvae. For example, because $H$. infernalis has been collected in southern and in some central areas in the Iberian Peninsula (González et al., 1992 and Zamora-Muñoz et al., 1995), we cannot ensure, without pupae or adult specimens, that our larval samples from the Turia basin are truly $H$. infernalis.

\section{Hydropsyche instabilis (Curtis, 1834)}

Material studied: 697L, 5Pơ $\sigma^{7}$ (VII), $7 \sigma^{7} \sigma^{7}$ (II, VII, VIII). Ter Basin: T10, T11, T12, TM4; Besòs Basin: B35; Llobregat Basin: L54, L56; Mijares Basin: MI4; Turia Basin: TU4, TU6; Júcar Basin: JU7, JU8; Segura Basin: SE1, SE3; Almanzora Basin: AL2, AL6, AL7; Adra Basin: AD4, AD5; Guadalfeo Basin: GU1, GU2, GU3, GU5, GU6, GU7, GU8, GU9, GU11, GU12, GU13, GU14, GU15, GU16

\section{Hydropsyche gr. instabilis}

MATERIAL STUdiEd: 93L, 4Pơ o' (VII, VIII). Llobregat Basin: L44; Foix Basin: F24, F25; Mijares Basin: MI3, MI7; Júcar Basin: JU1, JU7, JU15, JU17; Segura Basin: SE1

The male genitalia of the pupa of $H$. gr. instabilis resemble those of $H$. infernalis and $H$. fontinalis (González, pers. com., 2001). However, more pupae and adults are required to confirm whether $H$. gr. instabilis is a new species. Like $H$. infernalis and $H$. fontinalis, the larva of this species lacks gills on the 7 th abdominal segment, but its apotome pattern is easily distinguishable from that of $H$. infernalis and $H$. fontinalis (Figs. $2 \mathrm{~d}$ to $2 \mathrm{f}$ ). The shape of the apotome of $H$. gr. instabilis (Fig. $2 \mathrm{f}$ ) is wide and not as triangular as in $H$. fontinalis (Fig. 2e), with 


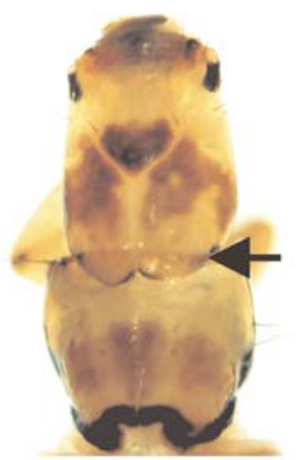

a

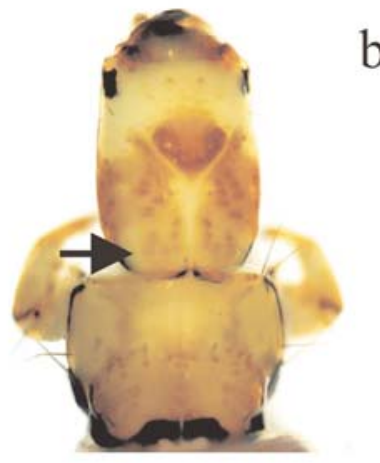

d

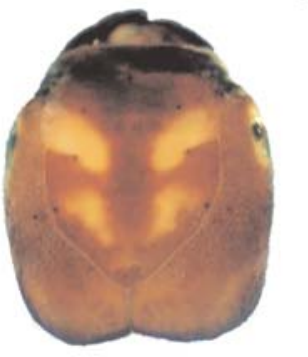

$\mathrm{g}$

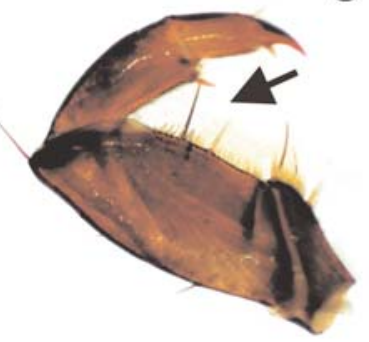

b

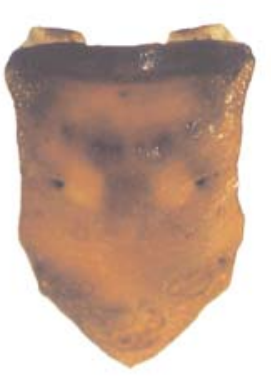

$\mathrm{C}$

$\mathrm{e}$

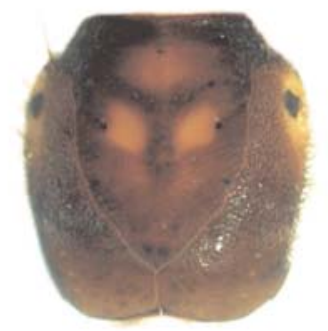

$\mathrm{h}$

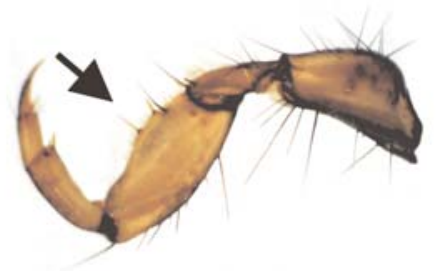

i

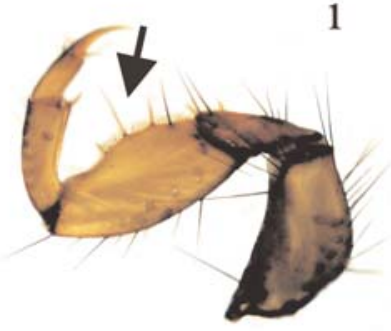

Fig. 2.- Larvae found in sampled Mediterranean basins. a) cephalic capsule and pronotum of Rhyacophila dorsalis; b) cephalic capsule and pronotum of $R$. nevada; c) apotome of Hydrosyche cf. acinoxas; d) cephalic capsule of H. infernalis; e) cephalic capsule of $H$. fontinalis; f) cephalic capsule of $H$. gr. instabilis; g) first leg of Glyphotaelius pellucidus; h) first leg of Mesophylax aspersus with two ventral setae; i) first leg of M. aspersus with three ventral setae.

Fig. 2.- Larvas de las cuencas Mediterráneas muestreadas. a) cápsula cefálica y pronoto de Rhyacophila dorsalis; b) cápsula cefálica y pronoto of $R$. nevada; c) apotoma de Hydrosyche cf. acinoxas; d) cápsula cefálica de H. infernalis; e) cápsula cefálica de H. fontinalis; f) cápsula cefálica de H. gr. instabilis; g) primera pata de Glyphotaelius pellucidus; h) primera pata de Mesophylax aspersus con dos sedas ventrales; i) primera pata de M. aspersus con tres sedas ventrales.

the posterior vertex not very pointed. In both species a dark Y-shaped patch stands out in the central area of the apotome, but is more conspicuous in $H$. fontinalis. $H$. gr. instabilis lacks the oral light spot present in $H$. fontinalis, and the two lateral light spots on the epistomal sulcus are indistinct and extending to the posterior vertex following the lower arm of the Y-shaped central patch. Both lar- vae of $H$. gr. instabilis and $H$. infernalis have wide and pentagonal apotomes but the principal difference between both species is in the pattern of the light spots of the apotome (Figs. 2d and 2f). In contrast to the above described pattern of $H$. gr. instabilis, $H$. infernalis has two pairs of lateral light spots (on and under the epistomal sulcus), often joined, leaving a dark and elongated wide patch in the central 
area of the apotome (Fig. 2d), and sometimes a light oral and aboral spots can also be distinguished (Zamora-Muñoz et al., 1995).

\section{Hydropsyche siltalai Döhler, 1963}

Material StUdied: 1876L, 2Po $\sigma^{x}$ (VII, VIII). Ter Basin: TM3; Tordera Basin: ToM8, ToM9, ToM11; Besòs Basin: B25, B7a, B28, B22, B35, B32, B36; Llobregat Basin: L42, L54, L60a; Júcar Basin: JU6, JU8; Segura Basin: SE5, SE18

In northwestern Spain, $H$. siltalai presents a high variability in head colour pattern, with the light aboral spot being more frequently $\mathrm{V}$ - than Ushaped (Vieira-Lanero, 2000; Vieira-Lanero, pers. com., 2001). Our specimens from northern basins always showed a U-shaped spot, similar to other specimens collected in central Spain (see ZamoraMuñoz et al., 1995).

Until the description of the larva of $H$. infernalis (Zamora-Muñoz et al., 1995), the only European species lacking gills on the $7^{\text {th }}$ abdominal segment was $H$. siltalai. This fact questions the records in the Ibeiran Peninsula based only on larval identifications previous to the description of $H$. infernalis, especially those from southern Spain, where $H$. infernalis is predominant.

Hydropsyche tibialis McLachlan, 1884

Material StUdied: 7L. Guadalfeo Basin: GU1, GU11

Cheumatopsyche Wallengren, 1891

Cheumatopsyche lepida (Pictet, 1834)

Material StUdied: 2L, 1Pơ (X). Llobregat Basin: L42; Júcar Basin: JU2, JU3, JU4, JU12, JU13; Segura Basin: SE5

Family ECNOMIDAE Ulmer, 1903

Ecnomus McLachlan, 1864

Ecnomus deceptor McLachlan, 1884

Material StUdied: 1L, 1Pơ (VI). Llobregat Basin: L77; Guadalquivir Basin: GE (C. Solà, leg)

Family PSYCHOMYIIDAE Walker, 1852

Subfamily Psychomyiinae Walker, 1852

Psychomyia Latreille, 1829

Psychomyia pusilla (Fabricius, 1781)

Material studied: 10L, $20^{\top} \sigma^{\top}$ (VII). Ter Basin: T21; Llobregat Basin: L42, L68; Júcar Basin: JU3, JU9
Lype McLachlan, 1878

Lype reducta (Hagen, 1868)

Material studied: 5L, $2 \sigma^{\pi} \sigma^{\pi}$ (IV). Besòs Basin: B25, B35; Segura Basin: SE2, SE18

Larvae collected in the Segura Basin expands the distribution area of Lype reducta to the southeast of the Iberian Peninsula.

\section{Metalype Klapálek, 1898}

Metalype fragilis (Pictet, 1834)

MATERIAL STUdied: 8L. Segura Basin: SE1

\section{Tinodes Curtis, 1834}

Three species whose larvae have not been described have been cited in the south of Spain: T. algiricus McLachlan, 1880, T. maroccanus Mosely, 1938 and T. baenai González \& Otero, 1984 (González et al., 1992). Consequently, it was difficult to identify our larval samples, especially from southern basins. The identification of the following specimens were obtained from already known larvae and should be interpreted with care.

Tinodes assimilis McLachlan, 1865

MAterial StUdied: 13L, $10^{7}$ (VII). Llobregat Basin: L56; Segura Basin: SE1; Almanzora Basin: AL6, AL7, AL11, AL14; Aguas Basin: AG2; Guadalfeo Basin: GU1

Tinodes dives (Pictet, 1834)

Material StUdied: 11L. Llobregat Basin: L44, L45, L56; Júcar Basin: JU6

Tinodes maclachlani Kimmins, 1966

MATERIAL STUDiEd: 2L. Llobregat Basin: L44, L45

Tinodes maculicornis (Pictet, 1834)

Material STUdied: 7L. Besòs Basin: B36; Almanzora Basin: AL17

Tinodes waeneri (Linnaeus, 1758)

Material studied: 34L, $10^{7}$ (IV). Besòs Basin: B28, B32, B35; Llobregat Basin: L60c, L102; Segura Basin: SE7 
Family POLYCENTROPODIDAE Ulmer, 1903 Subfamily Polycentropodinae Ulmer, 1903

Plectrocnemia Stephens, 1836

We recorded specimens of Plectrocnemia in the Besòs, Llobregat, Turia, Júcar, Segura, Adra and Guadalfeo basins. However, because of the difficulty to differentiate larvae, especially when they are not full-grown (Vieira-Lanero, 2000), we present here records from pupae and adults only.

Plectrocnemia geniculata McLachlan, 1871

Material studied: $10^{\pi}$ (IV). Foix Basin: F7a

Plectrocnemia laetabilis McLachlan, 1880

Material studied: 1Pơ (V), $3 \sigma^{\pi} \sigma^{\pi}$ (VII, VIII). Foix Basin: F33; Noguera Ribagorçana Basin: OUT0m, INLET

\section{Polycentropus Curtis, 1835}

Polycentropus flavomaculatus (Pictet, 1834)

Material StUdied: 170L, 2Pơ $\sigma^{7}$ (VIII), $80^{7} \sigma^{7}$ (IV, V, VIII). Ter Basin: T3, T10; Llobregat Basin: L38, L42, L44, L54, L56, L60a, L60c, L61, L64a, L68; Besòs Basin: B10, B22, B32, B35

Polycentropus kingi McLachlan, 1881

MATeRIAL STUdied: 175L. Besòs Basin: B32; Júcar Basin: JU17; Segura Basin: SE1, SE2, SE3, SE4, SE7; Almanzora Basin: AL6, AL7, AL8, AL10, AL11; Aguas Basin: AG2, AG7; Guadalfeo Basin: GU5

\section{Cyrnus Stephens, 1836}

Cyrnus cf. montserrati González \& Otero, 1983

Material StUdied: 7L. Segura Basin: SE2

Although no pupae or adults were collected in the study area, and larvae of $C$. montserrati are not described, the specimens found presented a distinct head colour pattern close to that of $C$. cintranus (Vieira-Lanero, pers. com., 2001). Moreover, in the first abdominal segment, our specimens had 2 setae sa3 and larvae of $C$. cintranus present only 1 setae in this position (Vieira-Lanero, 2000).

Suborder INTEGRIPALPIA

Superfamily LIMNEPHILOIDEA Kolenati, 1848

Family BRACHYCENTRIDAE Ulmer, 1903

Brachycentrus Curtis, 1834

Brachycentrus (O.) maculatum (Fourcroy, 1785)

Material StUdied: 8L. Llobregat Basin: L68; Guadalfeo Basin: GU3
Micrasema McLachlan, 1876

Micrasema longulum McLachlan, 1876

Material StUdied: 27L. Adra Basin: AD5; Guadalfeo Basin: GU1, GU2, GU5, GU15

Micrasema minimum McLachlan, 1876

Material Studied: 28L. Ter Basin: T3, T8, T10; Segura Basin: SE4

Larvae in the Segura basin expands the distribution area of Micrasema minimum to the southeast of the Iberian Peninsula.

Micrasema moestum (Hagen, 1868)

Material Studied: 212L. Segura Basin: SE1; Almanzora Basin: AL6, AL7, AL8; Adra Basin: AD5; Guadalfeo Basin: GU1, GU2, GU3, GU5, GU11, GU12, GU15

Some of the larvae collected displayed a similar, although less conspicuous, pattern as $M$. gr. moestum sensu Vieira-Lanero (2000).

Family LEPIDOSTOMATIDAE Ulmer, 1903

Subfamily Lepidostomatinae Ulmer, 1903

Lepidostoma Rambur, 1842

Lepidostoma hirtum (Fabricius, 1775)

Material studied: 14L. Tordera Basin: ToM6, ToM8, ToM10, ToM11

\section{Lasiocephala Costa, 1857}

Lasiocephala basalis (Kolenati, 1848)

MATERIAL STUDIED: 417L, 13P $\sigma^{x} \sigma^{x} 10 \mathrm{P}$ ㅇ ㅇ (VII), $12 \sigma^{x} \sigma^{x}$ 11 우 우 (V, VII). Tordera Basin: ToM10, ToM11; Turia Basin: TU6; Júcar Basin: JU7, JU8; Segura Basin: SE1; Adra Basin: AD5; Guadalfeo Basin: GU1, GU2, GU3, GU5, GU9, GU11, GU12, GU13, GU14, GU15

Subfamily Theliopsychinae Weaver, 1993 Crunoecia McLachlan, 1876

Crunoecia irroata (Curtis, 1834)

Material studied: 3L. Besòs Basin: B29

Family LIMNEPHILIDAE Kolenati, 1848 Subfamily Drusinae Banks, 1916

Drusus Stephens, 1837

Drusus bolivari (McLachlan, 1880)

Material Studied: 17L. Segura Basin: SE1, SE4 
Drusus discolor (Rambur, 1842)

Material studied: 5L. Ter Basin: T10, T18; Noguera Ribagorçana Basin: OUT200m

\section{Drusus rectus (McLachlan, 1868)}

Material STUdied: 167L, $10^{\top} 5$ 우 우 (VII). Ter Basin: T10, T19; Noguera Ribagorçana Basin: OUT0m, OUT200m, INLET

It is difficult to distinguish $D$. rectus from $D$. annulatus. There are records of adults of both species in the Pyrenees (see González et al., 1992) but no larval keys are available to differentiate them. Hiley (1970), Szczesny (1978), Wallace et al. (1990) and Waringer \& Graf (1997) include only $D$. annulatus, whereas Décamps \& Puyol (1975) reported only $D$. rectus. Because it was not possible to distinguish these two species using existing keys, and no pupae or adults of $D$. annulatus were collected, we provisionally considered all specimens as D. rectus

\section{Anomalopterygella Fischer, 1966}

\section{Anomalopterygella chauviniana (Stein, 1874)}

Material STUdied: 27L, $10^{7}$ (X). Ter Basin: T12; Adra Basin: AD5; Guadalfeo Basin: GU1, GU15

Subfamily Limnephilinae Kolenati, 1848

TrIBUS Limnephilini Kolenati, 1848

Limnephilus Leach, 1815

Limnephilus guadarramicus Schmid, 1955

Material StUdied: 103L, $20^{7} 0^{7}$ (IV). Besòs Basin: B7, B24, B28; Llobregat Basin: L42, L44, L45, L60a, L61, L64a, L77; Mijares Basin: MI1, MI3, MI8, MI10; Turia Basin: TU1, TU5; Júcar Basin: JU6, JU8, JU17; Aguas Basin: AG5

This species presents high variability in case morphology, from entirely mineral (see original description in Vera, 1979) to organic (twigs disposed tangentially, see Vieira-Lanero, 2000). We found types of both cases, although the latter was more frequent.

Specimens collected in central and some southern basins expand the distribution area of Limnephilus guadarramicus in the Iberian Peninsula.

Limnephilus lunatus Curtis, 1834

Material StUdied: 3L, 2Pơ ơ (IV). Llobregat Basin: L64a, L77
Glyphotaelius Stephens, 1833

Glyphotaelius pellucidus (Retzius, 1783)

Material StUdied: 20L, 2P $\sigma^{7} \sigma^{7} 1 \mathrm{P} \%$ (II, IV), $4 \sigma^{7} \sigma^{7} 1$ (II). Ter Basin: SO; Besòs Basin: B7, B7a

Prat et al. (1983) recorded G. pellucidus larvae in the Besòs basin. Because no pupae or adults have been collected in Spain, Vieira-Lanero (2000) considered that its presence required confirmation. We obtained several pupae and adults of $G$. pellucidus after rearing larvae from the Besòs basin, which showed the characteristic genitalia and anterior wing morphology (see Schmid, 1952; Malicky, 1983). Our observation confirms the presence of this species in the Iberian Peninsula. Moreover, the larvae fitted the keys by Waringer \& Graf (1997) and Vieira-Lanero (2000) very well, showing 2 ventral setae of distinct colour in the first femur (Fig. 2g). Most of the specimens collected had a typical case made of round pieces of litter arranged in the characteristic way, although others used nonrounded pieces disposed longitudinally. On the other hand, some collected Potamophylax sp. (see below) built a similar case to the one from Glyphotaelius, a characteristic observed by other authors (e.g. Wallace et al., 1990, Vieira-Lanero, 2000). In our study, G. pellucidus was found exclusively in the headwaters of temporary rivers, and had an earlier flight period than in more temperate climates (Sommerhäuser et al., 1997).

\section{TRIBUS Chaetopterygini Hagen, 1858 \\ Chaetopteryx Stephens, 1829}

We recorded the larvae of Chaetopteryx in the Ter, Besòs, Llobregat, Turia, Júcar, Segura and Guadalfeo basins. Because of the difficulty to identify larvae at species level, only records from pupae and adults are presented.

\section{Chaetopteryx villosa (Fabricius, 1798)}

Material STUdied: 1 ㅇ (X). Ter Basin: T10

TRIBUS Stenophylacini Schmid, 1955

Potamophylax Wallengren, 1891

Potamophylax cingulatus (Stephens, 1837)

Material StUdied: 194L, 5P $0^{7} 0^{7} 2 \mathrm{P}$ 우 우 (VIII), $10^{7} 2$ 우 우 (VIII). Ter Basin: TM1, TM2, TM3, TM4, T8, T9, T10, T11; Tordera Basin: ToM13, ToM15; Besòs Basin: B35; Llobregat 
Basin: L54, L56; Noguera Ribagorçana Basin: INLET; Júcar Basin: JU1

\section{Potamophylax latipennis (Curtis, 1834)}

Material Studied: 257L, 8P $0^{7} \sigma^{7} 12 \mathrm{P}$ 우 우 (VIII), $100^{7} 0^{7} 3$ 우 우 (II, VII, VIII, X). Ter Basin: T7, T9, T10, T12, TM1, TM3, TM4, TM5; Tordera Basin: ToM7, ToM8; Besòs Basin: B8a, B29, B35, B36; Llobregat Basin: L54, L56, L60a; Adra Basin: AD5; Guadalfeo Basin: GU1, GU11, GU15

\section{Halesus Stephens, 1836}

\section{Halesus digitatus (Schrank, 1781)}

Material studied: 51L, $20^{\top} \sigma^{\top}$ (VII, X). Ter Basin: T8, T10, T12; Besòs Basin: B35; Llobregat Basin: L44, L54, L68; Noguera Ribagorçana Basin: OUT200m

\section{Halesus radiatus (Curtis, 1834)}

Material STUdied: 103L. Ter Basin: T7, TM1, TM4, TM5; Tordera Basin: ToM6, ToM7, ToM8, ToM10, ToM11, ToM12, ToM15; Besòs Basin: B7a, B8a, B32, B35, B36; Llobregat Basin: L44, L56, L68; Mijares Basin: MI7; Turia Basin: TU1, TU2, TU4; Júcar Basin: JU1, JU7, JU8

\section{Halesus tessellatus (Curtis, 1834)}

MATERIAL STUDIED: 142L. Besòs Basin: B35; Turia Basin: TU1, TU2; Júcar Basin: JU7, JU8; Segura Basin: SE1, SE3, SE4; Adra Basin: AD5; Guadalfeo Basin: GU1, GU5, GU11, GU12, GU15

Although we did not find pupae or adults, Zamora-Muñoz \& Alba-Tercedor (1995) reported this species in the Iberian Peninsula. According to Panzenböck \& Waringer (1997) our larvae were identified as $H$. tessellatus. An analysis of the pupae and adult material is required to confirm the presence of $H$. tessellatus in northern basins.

\section{Stenophylax Kolenati, 1848}

It is difficult to identify Stenophylax species in the Iberian Peninsula because of numerous undescribed larvae. Therefore, we include only the pupae or adults collected. The larvae of this genus were found in several temporary streams in the Besòs, Júcar, Segura, Almanzora and Guadalfeo basins.

Stenophylax espanioli Schmid, 1957.

Material studied: 2Po $\sigma^{\top}(\mathrm{X}), 10^{\pi}(\mathrm{X})$. Ter Basin: T10

The larvae of this species remain undescribed. In larval sclerites we found setae insertions at the anterior sides of meso- and meta-femora, which indicates that $S$. espanioli larvae are similar to that of $S$. permistus, according to Vieira-Lanero (2000).

\section{Mesophylax McLachlan, 1882}

\section{Mesophylax aspersus (Rambur, 1842)}

MATERIAL STUDIED: 316L, 11Po $\sigma^{\top} 1 \mathrm{P}$ ( (II, III, IV, V, VII), $480^{7}$ ơ $^{7} 14$ 우 우 (II, IV, V, XI). Besòs Basin: B7a, B12, B22, B24, B28, B32; Llobregat Basin: L42, L45, L60c; Foix Basin: F4, F7, F7a, F16, F28; Mijares Basin: MI1, MI3, MI7; Turia Basin: TU3, TU7; Júcar Basin: JU5; Segura Basin: SE3, SE8, SE10, SE13, SE15, SE16; Almanzora Basin: AL1, AL2, AL3, AL4, AL5, AL10, AL11, AL14; Adra Basin: AD4; Guadalfeo Basin: GU5, GU6, GU7

Although Malicky (1998) considers all Mesophylax species from the Iberian Peninsula as being $M$. aspersus, $M$. impunctatus has been recorded by other authors (see González et al., 1992). According to Wallace et al. (1990) and Waringer \& Graf (1997), these two species can be clearly differentiated by the number of ventral setae in the first femur: 2 in $M$. impunctatus and 3 in $M$. aspersus. In the laboratory, we reared several larvae with 2 ventral setae in the first leg, and only adults of $M$. aspersus were obtained $(\mathrm{n}=62)$. All larvae collected in the field presented 2 setae in both legs, except in three specimens, which had 2 setae in one femur (Fig. 2h) and 3 in the other (Fig. 2i). Therefore, we consider that this character is not useful to distinguish $M$. aspersus and $M$. impunctatus in the Iberian Peninsula because of its variability, which also can be related with the geographic variability shown by adults of $M$. aspersus (Botosaneanu, in letter, 2000). The unclear taxonomy of adults of these two species may explain why the differences between their larvae are also uncertain (González, pers. com., 2001). This species survives drought by adapting its lifecycle (e.g. Bouvet, 1974; Bournaud, 1971). In this regard, we observed (during laboratory rearing) that even when drought is imposed suddenly, mature pupae emerge very quickly.

\section{Allogamus Schmid, 1955}

\section{Allogamus auricollis (Pictet, 1834)}

Material Studied: 13L. Ter Basin: T1, T2, T12; Llobregat Basin: L44

Some specimens found in the Ter basin presented very long mineral cases, approximately double the larval size. 
Allogamus mortoni (Navás, 1907)

Material STUdied: 1Pơ (XI). Almanzora Basin: AL6

Although $A$. mortoni is abundant in some mountain ranges of southern Spain in the Mediterranean area (Aceituno-Castro et al., 1999), its larva is still undescribed. At sites where only $A$. mortoni was present, larvae showed a light band in the anterior part of the pronotum, as in $A$. ligonifer. In southern basins we collected 45 Allogamus larvae, most of which presented this pattern at the pronotum; however, pupae or adults are required to confirm their identity.

Family UENOIDAE Iwata, 1927

Subfamily Thremmatinae Martynov, 1935

Thremma McLachlan, 1876

Thremma gallicum McLachlan, 1880

Material studied: 9L. Noguera Ribagorçana Basin: OUT0m, OUT200m

Family GOERIDAE Ulmer, 1903

Subfamily Goerinae Ulmer, 1903

Silo Curtis, 1830

Silo graellsii E. Pictet, 1865

MATERIAl STUdied: 25L. Ter Basin: T1, T8, T11, T12, TM2, TM4, TM5; Tordera Basin: ToM7

\section{Superfamily LEPTOCEROIDEA Leach, 1815}

Family LEPTOCERIDAE Leach, 1815

Subfamily Leptocerinae Leach, 1815

TRIBUS Athripsodini Morse \& Wallace, 1976

Athripsodes Billberg, 1820

Genus Athripsodes includes several species whose distribution within the Mediterranean area remains undescribed (e.g. A. taounate). Therefore, although larvae from this genus were found in the Almanzora, Aguas, Adra and Guadalfeo basins, we include only pupae or adults.

Athripsodes albifrons (Linnaeus, 1758)

MAterial STUDied: 1P q (VII). Guadalfeo Basin: GU1

Ceraclea Stephens, 1829

Ceraclea sobradieli (Navás, 1917)

MATERIAL STUDIED: 2L. Júcar Basin: JU10
TRIBUS Mysacidini Burmeister, 1839

Mystacides Berthold, 1827

Mystacides azurea (Linnaeus, 1761)

MATERIAL STUdied: 62L. Tordera Basin: ToM8, ToM9, ToM11, ToM12; Besòs Basin: B24, B32, B35; Llobregat Basin: L44, L45, L61, L68; Mijares Basin: MI5; Turia Basin: TU10; Júcar Basin: JU2, JU10; Segura Basin: SE2, SE18

Tribus Oecetini Silfvenius, 1905

Oecetis McLachlan, 1877

We found larvae of Oecetis in the Segura basin, although it was not possible to identify the species because the larva of some species recorded near the Mediterranean area have not been described to date (e.g. O. grazalemae).

TrIBUs Setodini Morse, 1981

Setodes Rambur, 1842

Setodes argentipunctellus McLachlan, 1877

Material STUdied: 112L, 1P ㅇ (X). Turia Basin: TU12; Júcar Basin: JU2, JU6; Segura Basin: SE2, SE4, SE16; Almanzora Basin: AL2, AL6; Aguas Basin: AG1, AG2; Adra Basin: AD1, AD3; Guadalfeo Basin: GU16

TRIBUS Triaenodini Morse, 1981

Adicella McLachlan, 1877

Adicella reducta (McLachlan, 1865)

Material StUdied: 5L, 1 ㅇ (VII). Tordera Basin: ToM10, ToM12; Besòs Basin: B29; Guadalfeo Basin: GU1, GU11

Family CALAMOCERATIDAE Ulmer, 1905

Subfamily Calamoceratinae Ulmer, 1905

Calamoceras Brauer, 1865

Calamoceras marsupus Brauer, 1865

Material studied: 2L. Segura Basin: SE1, SE2

Family ODONTOCERIDAE Wallengren, 1891

Subfamily Odontocerinae Wallengren, 1891

Odontocerum Leach, 1815

Odontocerum albicorne (Scopoli, 1763)

Material StUdied: 201L, 3P $\sigma^{\pi} \sigma^{\pi}$ (IV, VI), $11 \sigma^{\pi} \sigma^{7}$ (VII, VIII). Ter Basin: T4, T7, T8, T10, T11, TM2, TM3, TM4, TM5; 
Tordera Basin: ToM6, ToM7, ToM8, ToM11, ToM12, ToM13, ToM14, ToM15; Besòs Basin: B8a, B12, B32, B35; Llobregat Basin: L54, L56, L60a

Superfamily SERICOSTOMATOIDEA Stephens, 1836 Family SERICOSTOMATIDAE Stephens, 1836

Sericostoma Latreille, 1825

It is difficult to distinguish larvae of Sericostoma. Therefore, we present only species confirmed by pupae or adults. A revision of the adults found in the Iberian Peninsula is needed because of their morphological variability (González, pers. com., 2001).

\section{Sericostoma pyrenaicum E. Pictet, 1865}

Material StUdied: 3P $\sigma^{x} \sigma^{x}$ (VII), $2 \sigma^{x} \sigma^{x}$ (IV). Besòs Basin: B32; Llobregat Basin: L54; Foix Basin: F11; Segura Basin: SE1

Our records from the Segura basin extend the distribution range of this species to southeast Spain.

Sericostoma vittatum Rambur, 1842

Material StUdied: $10^{7}$ (VII). Adra Basin: AD5.

\section{Schizopelex McLachlan, 1876}

The Iberian Peninsula hosts two species of this genus ( $S$. festiva and $S$. furcifera). Because $S$. furcifera remains undescribed, we present only species confirmed by pupae and adult specimens of this genus. Vieira-Lanero (2000) described some taxonomical features to distinguish Schizopelex from Sericostoma, but all the Sericostomatidae larvae that we collected were identified as Sericostoma.

\section{Schizopelex furcifera McLachlan, 1880}

Material Studied: 1Pơ (VIII), $10^{7}$ (VII). Ter Basin: T20; Tordera Basin: ToM7

Family BERAEIDAE Wallengren, 1891

Beraea Stephens, 1833

Beraea maurus (Curtis, 1834)

MATERIAL STUdieD: 2L. Besòs Basin: B29; Llobregat Basin: L44

\section{Discussion}

Compared with other temperate areas, Mediterranean Basin fauna are highly diverse, with a considerable level of endemicity and complexity as the result of the interaction of complex historical and ecological factors (Balletto \& Casale, 1991). However, in spite of the high caddisfly richness of the Iberian Peninsula (Gonzalez, 2003), the Mediterranean area is poorer in species than other less mediterranean zones in the north and especially northwest of Spain (González et al., 1987). This phenomenon has been related to ecological and historical factors though it also should be born in mind that the majority of studies were performed in the northern regions of the Iberian Peninsula, far from the Mediterranean area (González et al., 1987). A total of 90 species were identified in our study, which accounts for $27.7 \%$ of the species recorded and identified with confidence in the Iberian Peninsula. Although this percentage might seem poor, it must be stated that not all mediterranean basins have been sampled and not all collected larvae were identified to species level. The maximum diversity of caddisflies in the area sampled was found in regions with high-mountain influences (e.g. rivers from Pyrenees, Montseny and Sierra Nevada ranges) or those where northern and southern species mix (e.g. in the Segura basin). In addition, Mediterranean rivers in central and some southeastern areas (e.g. rivers from the Almería province) present a depleted caddisfly fauna (Bonada, 2003). This depletion may be related to the lack of extensive studies (González et al., 1987), but it is especially attributable to the harshness of the climate and to the high human impact on the southern arid regions.

The groups of species according to their distribution areas are shown in Figure 3, where sampling sites have been grouped into three sets (northern, central and southern basins) to facilitate interpretation. According to the literature, the species have been grouped into three categories depending on their distribution: widespread, Iberian-north African and endemic species of the Iberian Peninsula and/or Pyreness. Overall, most of the caddisflies collected in the area were widely distributed, which is in accordance with González et al. (1987). In comparison with northern and central basins, southern basins showed the highest proportion of endemic species, with a mix of species that are widely distributed around the Iberian Peninsula and those exclusive to the Baetic-Rift area. Our results emphasize the importance of southern basins as a speciation area for several groups of invertebrates (Ruiz et al., 2001).

On the basis of our results, the distribution areas of some caddisfly species could be expanded (Lype 

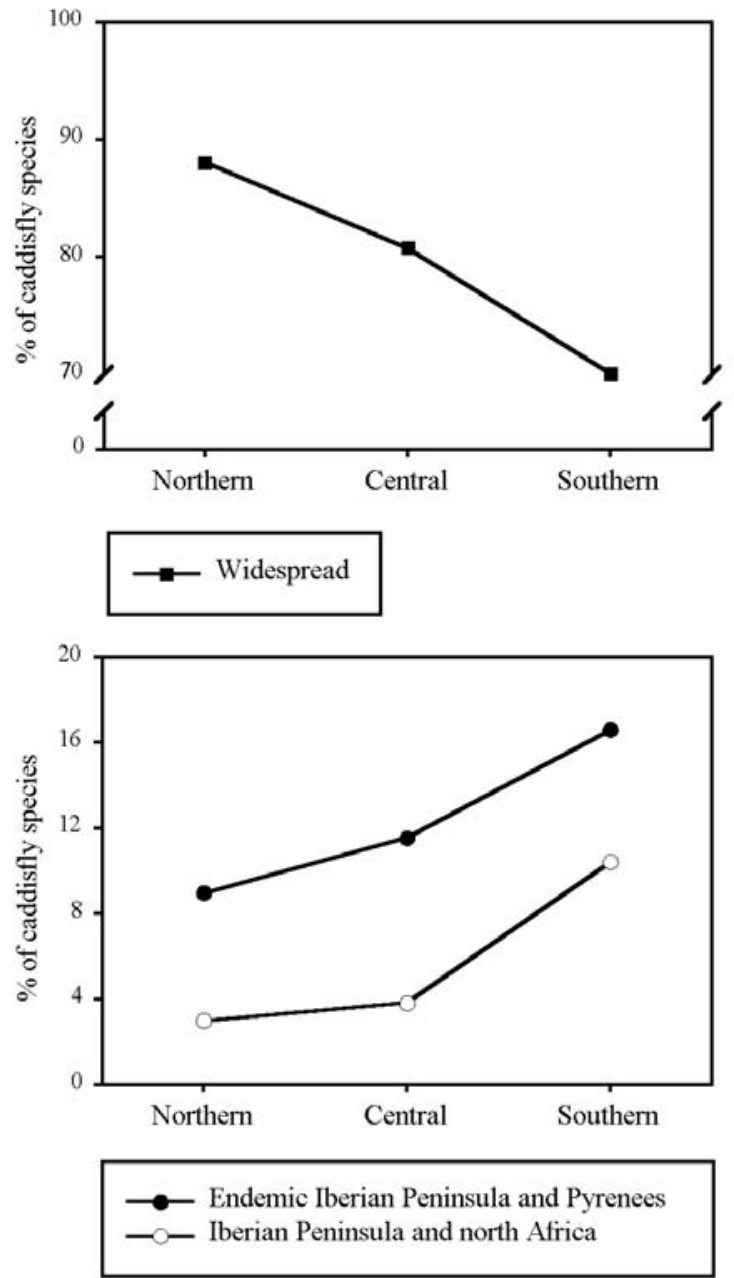

Fig. 3.- Percentage of caddisfly species with a widespread distribution, Iberian-north African and endemic species of the Iberian Peninsula and Pyrenees classified into three groups of basins sampled. Northern basins include the Ter, Tordera, Besòs, Llobregat, Foix and Noguera Ribagorçana. Central basins include the Mijares, Turia and Júcar. Southern basins include the Segura, Almanzora, Aguas, Adra, Guadalfeo and Guadalquivir. The graph is based on 89 species. Hydropsyche gr. instabilis has been omitted because the limits of its distribution are unknown.

Fig. 3.- Porcentaje de especies de distribución amplia, ibérico-norteafricana y endémicas de la Península Ibérica y Pirineos para cada uno de los tres grupos de cuencas vertientes al Mediterráneo. Las cuencas del norte incluyen: Ter, Tordera, Besòs, Llobregat, Foix y Noguera Ribagorçana. Las cuencas del centro incluyen: Mijares, Turia y Júcar. Las cuencas del sur incluyen: Segura, Almanzora, Aguas, Adra, Guadalfeo and Guadalquivir. El gráfico se ha obtenido con 89 especies. Hydropsyche gr. instabilis no ha sido incluido debido a que se desconocen sus límites de distribución. reducta, Micrasema minimum, Limnephilus guadarramicus, Sericostoma pyrenaicum). We also confirm the presence of others (e.g. Glyphotaelius pellucidus) and provide relevant taxonomic and ecological data for further studies.

\section{ACKNOWLEDGEMENTS}

This research was supported by GUADALMED Projects (HID98-0323-C05 and REN2001-3438-C07) and the junior author was granted a pre-doctoral grant by the Spanish Ministerio de Ciencia y Tecnología. The authors thank all the members of the GUADALMED and ECOBILL projects for data collection and chemical analysis. We are very grateful to Dr. Marcos A. González, Dr. Fernando Cobo, Dr. Rufino VieiraLanero and Dr. María José Serviá for their help in caddisfly identification. We also thank to Dr. Lazare Botosaneanu and Dr. Hans Malicky for valuable comments, two anonymous referees whose comments and suggestions improved the manuscript, and Dr. Antonio Ruiz for providing useful information.

\section{References}

Aceituno-Castro, E., Luzón-Ortega, J. M., Tierno de FigueroA, J. M., GonZÁlez-Chamorro, B., JÁimezCuéllar, P. \& Zamora-Muñoz, C., 1999. Contribución al conocimiento de los insectos acuáticos de la Sierra de Huétor (Granada, España). XVII Jornadas de la Asociación española de Entomología, Bilbao: 58.

Alba-Tercedor, J. \& SÁnchez-Ortega, A., 1988. Un método rápido y simple para evaluar la calidad biológica de las aguas corrientes basado en el de Hellawell (1978). Limnetica, 4: 51-56.

Alba-Tercedor, J., Jáimez-Cuéllar, P., Álvarez, M., Avilés, J., Bonada, N., Casas, J., Mellado, A., Ortega, M., Pardo, I., Prat, N., Rieradevall, M., Robles, S., Sáinz-Cantero, C. E., SÁnchezOrtega, A., Suárez, M. L., Toro, M., VidalABARCA, M. R., Vivas \& ZaMORA-MuÑOZ, C., 2002. Caracterización del estado ecológico de ríos mediterráneos ibéricos mediante el índice IBMWP (antes BMWP'). Limnetica, 21: 175-185.

Balletto, E. \& Casale, A., 1991. Mediterranean insect conservation. In: N.M. Collins \& J.A. Thomas (eds.). The conservation of insects and their habitats. Academic Press. London: 122-142.

BASAguren, A., 1990. Los tricópteros de la red hidrográfica de Bizkaia. PhD. Universidad del País Vasco. 603 pp.

BonADA, N., 2003. Ecology of the macroinvertebrate communities in mediterranean rivers at different scales and organization levels. Ph.D. University of Barcelona. Barcelona. 355 pp. Available in PDF in http://www.tdx.cbuc.es/

BouRnAUD, M., 1971. Observations biologiques sur les trichoptères cavernicoles. Bulletin Mensuel de la Société Linnéenne de Lyon, 7: 197-211. 
Bouvet, Y., 1974. Ecologie et reproduction chez les Trichoptères cavernicoles du groupe de Stenophylax (Limnephilidae, Stenophylacini). Proceedings of the $1^{\text {st }}$ International Symposium on Trichoptera: 105-109.

Buholzer, H., 1978. Larvenmorphologie und Verbreitung der schweizerischen RHYACOPHILA-Arten (Trichoptera, Rhyacophilidae). Dissertation ETH Nr. 6177. Zürich. $151 \mathrm{pp}$.

CiAnficconi, F., 2002. The third list of Italian Trichoptera (1990-2000). Proceedings of the $10^{\text {th }}$ International Symposium on Trichoptera, 15: 349-358.

CONACHER, A. J. \& SAla, M., 1998. Land degradation in Mediterranean environments of the world: Nature and extent cause and solutions. John Wiley \& Sons Ltd. Chichester. 491 pp.

DÉCAMPS, H., 1965. Larves Pyrénéennes du genre Rhyacophila (Trichoptères). Annales de Limnologie, 181): 51-72.

DÉCAMPS, H. \& PUYOL, J. Y., 1975. Les larves de Drusinae des Pyrénées (Trichoptères, Limnephilidae). Annales de Limnologie, 11(2): 157-167.

DesPax, R., 1928. La larve et la nymphe de Rhyacophila denticulata McLachlan (Trichoptera). Bulletin de la société d'Históire Naturelle de Toulousse, 62: 149-155.

Edington, J. M. \& Hildrew, A. G., 1981. A key to the caseless caddis larvae of the British Isles with notes on their ecology. Scientific publications of the Freshwater Biological Association, 43: 1-92.

Edington, J. M. \& Hildrew, A. G., 1995. A Revised Key to the Caseless Caddis Larvae of the British Isles, with Notes on their Ecology. Freshwater Biological Association Publications. Ambleside. 134 pp.

FILBÀ, L., 1986. Tricòpters recol-lectats al Montseny. I Jornada de Recerca Naturalista al Montseny: 61-63.

GALlARDO-MAYENCO, A., 1993. Macroinvertebrate associations in two basins of SW Spain. Archive für Hydrobiologie, 127(4): 473-483.

Gallardo-Mayenco, A., Prenda, J. \& Toja, J., 1998. Spatio-Temporal distribution and ecological preferences of coexisting hydropsychid species (Trichoptera) in two Mediterranean river Basins (S Spain). International Review of Hydrobiology, 83(2): 123-134

GARCíA DE JALÓN, D., 1982. Contribución a la zoogeografía de los tricópteros españoles. SHILAP Revista de lepidopterología, 10(37, 38, 39): 75-78, 157-155, 237-244.

GARCíA DE JALÓN, D., 1986. Los Hydropsychidae (Trichoptera) de la cuenca del Duero. Boletín de la Asociación Española de Entomología, 10: 127-138.

GonzÁlez, M. A., García de Jalón, D. \& Terra, L., 1987. Faunistic studies on Iberian Trichoptera: A historical survey and present state of knowledge. Proceedings of the $5^{\text {th }}$ International Symposium on Trichoptera: 85-90.
GonzÁlez, M. A., Terra, L. S. W., García de Jalón, D. \& CoBO, F., 1992. Lista faunística y bibliográfica de los Tricópteros (Trichoptera) de la Península Ibérica $e$ Islas Baleares. Asociación Española de Limnología, 11. 200 pp.

GonzÁlez, M. A. \& Ruiz, A., 2001. Une nouvelle espèce de Trichoptère du Sud de 1'Espagne: Allogamus gibraltaricus n. sp. (Trichoptera: Limnephilidae). Annales de Limnologie, 37(3): 219-221.

GonzÁlez, M. A., 2003. El Reino Animal en la Península Ibérica y las Islas Baleares. Orden Trichoptera. http://www.fauna-iberica.mncn.csic.es/htmlfauna/faunibe/zoolist/insecta/trichoptera/trichoptera.html

González del TÁnAgo, M. \& García de Jalón, D., 1984. Desarrollo de un índice biológico para estimar la calidad del las aguas de la cuenca del Duero. Limnetica, 1: 263-272.

Herranz, J. M. \& García de Jalón, D., 1984. Distribución de las especies del género Hydropsyche (Trichoptera, Hydropsychidae) en la cuenca del alto Tajo (Guadalajara). Limnetica, 1: 203-206.

HiLEy, P. D., 1970. A key to the larvae of four distinct limnephilids: Drusus annulatus Stephens, Ecclisopteryx guttulata (Pictet), Apatania muliebris McLachlan and Ironoquia dubia (Stephens) (Trichoptera: Limnephilidae). Entomologist's Gazette, 21: 289-294.

KöPpen, W., 1923. Die Klimate der Erde. Bornträger. Berlin. 369 pp.

MALICKY, H., 1981. Weiters Neues über Köcherfliegen aus dem Mittelmeergebiet (Trichoptera). Entomofauna (Zeitschrift für Entomologie), 2(27): 335-356.

Malicky, H., 1983. Atlas of European Trichoptera. Dr. W. Junk Publishers. The Hague. 298pp.

MALICKY, H. \& LounACI, A., 1987. Beitrag zur Taxonomie und Faunistik der Köcherfliegen von Tunesien, Algerien und Marokko (Trichoptera). Opuscula Zoologica Fluminensia, 14: 1-20.

Malicky, H. \& Sipahiler, F., 1993. Köcherfliegen (Tricoptera) ans der Türkei mit Bemerkungen zu weiteren mediterranen Köcherfliegen. Bulletin de la Société Entomologique Suisse, 66: 457-478.

MALICKY, H., 1997. Die mediterranean, vorderasiatischen und europäischen Arten des Hydroptila sparsa Gruppe (Trichoptera, Hydroptilidae). Entomologische Berichte Luzern, 38: 137-53.

MALICKY, H., 1998. Revision der Gattung Mesophylax McLachlan. Beiträge zur Entomologie, 48(1): 115-144.

Malicky, H., 2002. The sub-specific division of Rhyacophila dorsalis Curtis, 1834 and its transitions to $R$. nubila Zetterstedt, 184 (Trichoptera: Rhyacophilidae). Proceedings of the $10^{\text {th }}$ International Symposium on Trichoptera, 15: 149-166.

PANZENBÖCK, M. \& WARINGER, J., 1997. A key to fifth instar larvae of Halesus radiatus Curtis 1834 , Halesus digitatus Schrank 1781 and Halesus tessella- 
tus Rambur 1842 (Trichoptera: Limnephilidae), based on Austrian material. Aquatic Insects, 19(2): 65-73.

PiCAzO-MuÑoz, J., 1995. Caracterización y calidad de las aguas de los cauces de la cuenca del río Guadiana Menor. Aspectos fisico-químicos y macroinvertebrados acuáticos. PhD. Universidad de Granada. Granada. 256 pp.

Prat, N., Puig, M. A. \& González, G., 1983. Predicció $i$ control de la qualitat de les aigües dels rius Besòs $i$ Llobregat II. Diputació de Barcelona. Barcelona. $164 \mathrm{pp}$.

Prat, N., Rieradevall, M., Munné, A., Solà, C. \& BONADA, N., 1999. La qualitat ecològica del Llobregat, el Besòs $i$ el Foix. Informe 1997. Diputació de Barcelona. Barcelona. 154 pp.

Prat, N., Rieradevall, M., Munné, A., Solà, C. \& BONADA, N., 2001. La qualitat ecològica del Llobregat, el Besòs, el Foix $i$ la Tordera. Informe 1991. Diputació de Barcelona. Barcelona. 171 pp.

Prat, N., Vila-Escalé, M. \& Jubany, J., 2000. Estat ecològic dels rius $i$ rieres de la conca del riu Ter. Projecte de recerca per a ALBATER. Grup ECOBILL. 49 pp.

PRAT, N. \& WARD, J. V., 1994. The tamed river. In: R. Margalef (ed.). Limnology Now: A Paradigm of Planetary Problems. Elsevier Science. London: 219-236.

Puig, M. A., Bautista, I., Tort, M. J. \& Prat, N., 1981. Les larves de trichoptères de la riviere Llobregat (Catalogne, Espagne). Distribution longitudinale et relation avec la qualite de l'eau. Series Entomologica, 20: 305-311.

Rieradevall, M. \& Prat, N., 2000. El zoobentos en los lagos y lagunas de alta montaña de la península Ibérica y su interés como indicadores de cambios ambientales. In: I. Granados \& M. Toro (eds.). Conservación de los lagos y humedales de alta montaña de la península Ibérica. Ediciones de la Universidad Autónoma de Madrid. Madrid: 187-200.

Robles, S., Toro, M., Nuño, C., Avilés, J., AlbaTercedor, J., Álvarez, M., Bonada, N., Casas, J., Jáimez-CuÉllar, P., Mellado, A., Munné, A., Pardo, I., Prat, N., SuÁrez, M. L., Vidal-Abarca, M. R., VIVAS, S., MoyÀ, G. \& RAMON, G., 2002. Descripción de las cuencas mediterráneas seleccionadas en el proyecto GUADALMED. Limnetica, 21(3-4): 35-61.

Ruiz, A., SAlamanca-Ocaña, J. C. \& FerrerasRoMero, M., 2001. Fauna de tricópteros (Insecta: TRICHOPTERA) de cursos de agua que drenan canutos del Parque Natural de Los Alcornocales (sur de España). Boletín de la Asociación Española de Entomología, 25(3-4): 105-120.

Ruiz, A., Salamanca-Ocaña, J. C. \& FerrerasROMERO, M., in press. The larva of Agapetus incertulus McLachlan, 1884 (Trichoptera, Glossosomatidae). Aquatic Insects.
Schmid, F., 1952. Les genres Glyphotaelius Steph. et Nemotaulius Bks (Trichopt. Limnophil.). Bulletin de la Société Vaudoise des Sciences Naturelle, 65(280): 213-244.

SolÀ, C., 2001. Efecte de la contaminació minera sobre la comunitat de macroinvertebrats a la conca del riu Guadiamar. Memòria DEA. Universitat de Barcelona. Barcelona. 96 pp.

Sommerhäuser, M., Robert, B. \& Schuhmacher, H., 1997. Fligth periods and life history strategies of caddisflies in temporary and permanent woodland brooks in the Lower Rhine area (Germany). Proceedings of the $8^{\text {th }}$ International Symposium on Trichoptera: 425-433.

SzCZESNY, B., 1978. Larvae of the subfamily Drusinae (Insecta: Trichoptera) from the Polish part of the Carpathian Mts. Acta Hydrobiologica, 20(1): 35-53.

Terra, L. S. W., 1994. Atlas provisório dos Tricópteros (Insecta, Trichoptera) de Portugal Continental. Estudos e Informaçao, 360. Instituto Florestal, Vila do Conde. 100 pp.

Trabaud, L., 1981. Man and Fire: Impacts on mediterranean vegetation. In: F. di Castri, D.W. Goodall \& R.W. Specht (eds.). Mediterranean-Type Shrublands. Elsevier. New York: 523-537.

Usseglio-Polatera, P., 1992. Graphical expression of the ecological significance of a faunistic assemblage and its application to the study of the Rhône river Trichoptera at Lyons (France). Proceedings of the $7^{\text {th }}$ International Symposium on Trichoptera: 305-311.

VERA, R., 1979. La larva de Limnephilus guadarramicus Schmid, 1955 (Trich., Limnephilidae). Boletín de la Asociación Española de Entomología, 3: 65-71.

VIEDMA, M. G. \& GARCíA DE JALÓN, D., 1980. Description of four larvae of Rhyacophila (Pararhyacophila) from the Lozoya River, Central Spain, and key to the species of the Iberian Peninsula (Trichoptera: Rhyacophilidae). Aquatic Insects, 2(1): 1-12.

VIEIRA-LANERo, R., 1996. Contribución al conocimiento de las larvas de algunos Tricópteros (Insecta: Trichoptera) de Galicia. MSc. Universidad de Santiago de Compostela. Santiago de Compostela. $111 \mathrm{pp}$.

VIEIRA-LANERO, R., 2000. Las larvas de los tricópteros de Galicia (Insecta: Trichoptera). PhD. Universidade de Santiago de Compostela. Santiago de Compostela. 611pp.

Vieira-Lanero, R., GonzÁlez, M. A. \& CoBo, F., 2001. Descripción de las larvas de dos endemismos ibéricos del género Rhyacophila: R. melpomene Malicky, 1976 y $R$. laufferi Navás, 1918 (Trichoptera, Rhyacophilidae). Graellsia, 57(1): 29-37.

Wallace, I. D., Wallace, B. \& Philipson, G. N., 1990. A key to the case-bearing caddis larvae of Britain and Ireland. Freshwater Biological Association Publications. Ambleside. 237 pp. 
WARINGER, J. \& GRAF, W., 1997. Atlas der Östrreichischen Köcherfliegenlarven: unter Einschluss der angrenzenden Gebiete. Facultas-Universitätsverlag. Wien. 286 pp.

Wiggins, G. B., 1996. Larvae of the North American Caddisfly Genera (Trichoptera). $2^{\text {nd }}$ edition. University of Toronto Press. Toronto. $457 \mathrm{pp}$.

ZAMORA-MuÑoz, C., 1992. Macroinvertebrados acuáticos, caracterización y calidad de las aguas de los cauces de la cuenca alta del río Genil. PhD. Universidad de Granada. Granada. 255 pp.

ZAMORA-Muñoz, C. \& AlbA-Tercedor, J., 1992. Description of the larva of Rhyacophila (Rhyacophila) nevada Schmid, 1952 and key to the species of Rhyacophila of the Iberian Peninsula (Trichoptera: Rhyacophilidae). Aquatic Insects, 14(2): 65-71.

Zamora-Muñoz, C. \& Alba-Tercedor, J., 1995. Primera cita de Halesus tessellatus Rambur 1842 (Trichoptera: Limnephilidae) en la Península Ibérica. Boletín de la Asociación Española de Entomología, 19(3-4): 200-201.
Zamora-Muñoz, C., Alba-Tercedor, J. \& García DE JALÓN, D., 1995. The larvae of the genus Hydropsyche (Hydropsychidae; Trichoptera) and key for the identification of species of the Iberian Peninsula. Bulletin de la Société Entomologique Suisse, 68: 189-210.

Zamora-Muñoz, C., Picazo, J. \& Alba-Tercedor, J., 1997. New findings of the larval pattern variability in Rhyacophila meridionalis Pictet, 1865 (Trichoptera: Rhyacophilidae). Aquatic Insects, 19(1): 1-8.

Zamora-Muñoz, C., GonzÁlez, M. A., Picazo-Muñoz, J. \& AlBA-TERCEDOR, J., 2002. Hydropsyche fontinalis, a new species of the instabilis-group from the Iberian Peninsula (Trichoptera, Hydropsychidae). Aquatic Insects, 24(3): 189-197.
Recibido, 11-XI-2003

Aceptado, 14-VI-2004

Publicado, 25-VIII-2004 
Appendix.- Location of sampling sites. For each site the code used in the text, UTM coordinates, river name, province and altitude above the sea level are shown.

Apéndice.- Localización de las estaciones muestreadas. Para cada estación se presenta el código utilizado en el texto, las coordenadas UTM, el nombre del río, la provincia y la altitud.

\begin{tabular}{|c|c|c|c|c|c|}
\hline Site code & X_UTM & Y_UTM & Altitude (m.) & Stream/River & Province \\
\hline \multicolumn{6}{|l|}{ TER BASIN } \\
\hline $\mathrm{T} 1$ & 4416 & 46940 & 1440 & Ter & Girona \\
\hline T2 & 4425 & 46934 & 1380 & Ter/Carboners & Girona \\
\hline T3 & 4428 & 46874 & 1080 & Ter & Girona \\
\hline T4 & 4448 & 46862 & 1000 & Ter & Girona \\
\hline T5 & 4234 & 46790 & 1020 & Garfull & Girona \\
\hline $\mathrm{T7}$ & 4499 & 46926 & 1220 & Ritort & Girona \\
\hline T8 & 4506 & 46919 & 1200 & Ritort & Girona \\
\hline T9 & 4508 & 46910 & 1160 & Ritort & Girona \\
\hline T10 & 4513 & 46908 & 1180 & Fabert & Girona \\
\hline T11 & 4517 & 46888 & 1080 & Torrent de la Ginestosa & Girona \\
\hline T12 & 4484 & 46853 & 960 & Ritort & Girona \\
\hline T14 & 4476 & 46927 & 1420 & Torrent de la Casassa & Girona \\
\hline T15 & 4463 & 46869 & 920 & Feitús & Girona \\
\hline T16 & 4388 & 46703 & 920 & La Tolosa & Girona \\
\hline T17 & 4266 & 46851 & 1060 & Rigart & Girona \\
\hline T18 & 4295 & 46918 & 2060 & Fontalba & Girona \\
\hline T19 & 4303 & 46945 & 1980 & Torrent de Finestrelles & Girona \\
\hline T20 & 4419 & 46900 & 1180 & Ter & Girona \\
\hline T21 & 4515 & 46887 & 1060 & Ritort & Girona \\
\hline so & 4355 & 46648 & 640 & Riera de la Solana & Barcelona \\
\hline TM1 & 4428 & 46300 & 740 & Torrent de Valldoriola & Barcelona \\
\hline TM2 & 4466 & 46333 & 680 & Riera de la Sala & Girona \\
\hline TM3 & 4477 & 46336 & 700 & Riera Major & Girona \\
\hline TM4 & 4493 & 46320 & 800 & Torrent de Collpregon & Girona \\
\hline TM5 & 4522 & 46341 & 760 & Riera d'Espinelves & Girona \\
\hline \multicolumn{6}{|c|}{ TORDERABASIN } \\
\hline ToM6 & 4552 & 46306 & 480 & Riera d'Arbúcies & Girona \\
\hline ToM7 & 4575 & 46293 & 460 & Sot del Clot & Girona \\
\hline ToM8 & 4582 & 46299 & 360 & Riera d'Arbúcies & Girona \\
\hline ToM9 & 4631 & 46270 & 200 & Riera d'Arbúcies & Girona \\
\hline ToM10 & 4481 & 46249 & 480 & Riera de la Castanya & Barcelona \\
\hline ToM11 & 4484 & 46248 & 460 & Riera de Sant Marçal & Barcelona \\
\hline ToM12 & 4512 & 46265 & 780 & Riera de Sant Marçal & Barcelona \\
\hline ToM13 & 4529 & 46229 & 720 & Sot de I'Infern & Barcelona \\
\hline ToM14 & 4545 & 46258 & 1220 & Riera de Santa Fe & Barcelona \\
\hline ToM15 & 4555 & 46251 & 1140 & Riera de Santa Fe & Barcelona \\
\hline \multicolumn{6}{|c|}{ RIBERARIBAGORÇANABASIN } \\
\hline INLET & 3183 & 47234 & 2240 & Inlet to Lac Redon & Lleida \\
\hline OUTOm & 3179 & 47232 & 2220 & Barranc de Lac Redon & Lleida \\
\hline OUT200m & 3170 & 47231 & 2200 & Barranc de Lac Redon & Lleida \\
\hline \multicolumn{6}{|c|}{ BESÒS BASIN } \\
\hline B8a & 4458 & 46178 & 320 & Riera de Cànoves & Barcelona \\
\hline B10 & 4400 & 46145 & 220 & Congost & Barcelona \\
\hline B12 & 4296 & 46109 & 240 & Riera de Caldes & Barcelona \\
\hline B16 & 4373 & 46044 & 100 & Tenes & Barcelona \\
\hline B17a & 4315 & 46063 & 240 & Caldes & Barcelona \\
\hline B22 & 4211 & 46132 & 340 & Ripoll & Barcelona \\
\hline B24 & 4253 & 46165 & 560 & Gallifa & Barcelona \\
\hline B25 & 4327 & 46174 & 250 & Tenes & Barcelona \\
\hline B28 & 4308 & 46196 & 570 & Tenes & Barcelona \\
\hline B36 & 4381 & 46269 & 500 & Martinet & Barcelona \\
\hline
\end{tabular}


Appendix.- (Continued).

\begin{tabular}{|c|c|c|c|c|c|}
\hline Site code & X_UTM & Y_UTM & Altitude (m.) & Stream/River & Province \\
\hline B29 & 4422 & 46293 & 1000 & Avencó & Barcelona \\
\hline B30 & 4362 & 46293 & 530 & Congost & Barcelona \\
\hline B32 & 4397 & 46248 & 340 & Avencó & Barcelona \\
\hline B35 & 4403 & 46199 & 380 & Vallcàrquera & Barcelona \\
\hline B7a & 4490 & 46161 & 320 & Vilamajor & Barcelona \\
\hline B7 & 4540 & 46102 & 320 & Riera de les Arenes & Barcelona \\
\hline \multicolumn{6}{|c|}{ LLOBREGATBASIN } \\
\hline SC1 & 3999 & 46458 & 760 & Riera de Sant Cugat & Barcelona \\
\hline L100 & 4039 & 46151 & 165 & Cardener & Barcelona \\
\hline L101 & 4049 & 46135 & 150 & Llobregat & Barcelona \\
\hline L102 & 4061 & 46179 & 180 & Llobregat & Barcelona \\
\hline L38 & 4007 & 46232 & 220 & Cardener & Barcelona \\
\hline L39 & 3974 & 46300 & 250 & Cardener & Barcelona \\
\hline L42 & 3931 & 46373 & 386 & Cardener & Barcelona \\
\hline L43 & 3852 & 46448 & 425 & Cardener & Barcelona \\
\hline L44 & 3942 & 46322 & 630 & Negre & Barcelona \\
\hline L45 & 4158 & 46166 & 540 & Riera de les Nespres & Barcelona \\
\hline L54 & 4009 & 46769 & 720 & Llobregat & Barcelona \\
\hline L56 & 4164 & 46796 & 1360 & Llobregat & Barcelona \\
\hline L57 & 4138 & 46770 & 840 & Llobregat & Barcelona \\
\hline L60a & 4074 & 46601 & 487 & Llobregat & Barcelona \\
\hline L60c & 4073 & 46550 & 460 & Llobregat & Barcelona \\
\hline L61 & 4167 & 46531 & 550 & Merlès & Barcelona \\
\hline L64a & 4117 & 46283 & 320 & Gavarresa & Barcelona \\
\hline L67 & 4078 & 46395 & 320 & Llobregat & Barcelona \\
\hline L68 & 4071 & 46350 & 285 & Llobregat & Barcelona \\
\hline L77 & 3813 & 46049 & 310 & Anoia & Barcelona \\
\hline L82 & 3760 & 46121 & 465 & Veciana & Barcelona \\
\hline L90 & 4175 & 45848 & 20 & Llobregat & Barcelona \\
\hline L91 & 4137 & 45917 & 45 & Llobregat & Barcelona \\
\hline L94 & 4104 & 45953 & 60 & Llobregat & Barcelona \\
\hline L95 & 4068 & 46026 & 80 & Llobregat & Barcelona \\
\hline \multicolumn{6}{|c|}{ FOIX BASIN } \\
\hline F11 & 3825 & 45864 & 400 & Albareda & Barcelona \\
\hline F24 & 3753 & 45865 & 660 & Pontons & Barcelona \\
\hline F25 & 3765 & 45861 & 580 & Pontons & Barcelona \\
\hline \multicolumn{6}{|c|}{ MIJARES BASIN } \\
\hline MI1 & 6840 & 44770 & 1370 & Mijares & Teruel \\
\hline Ml10 & 6861 & 44561 & 950 & Valbona & Teruel \\
\hline $\mathrm{MI3}$ & 6839 & 44550 & 920 & Mijares & Teruel \\
\hline MI4 & 6987 & 44445 & 690 & Mijares & Teruel \\
\hline MI5 & 7212 & 44373 & 310 & Mijares & Castellón \\
\hline MI6 & 7375 & 44302 & 90 & Mijares & Castellón \\
\hline MI7 & 6900 & 44415 & 890 & Albentosa & Castellón \\
\hline MI8 & 7173 & 44561 & 760 & Villahermosa & Castellón \\
\hline MI9 & 7263 & 44380 & 300 & Villahermosa & Castellón \\
\hline \multicolumn{6}{|c|}{ TURIABASIN } \\
\hline TU10 & 6849 & 43860 & 200 & Turia & Valencia \\
\hline TU11 & 7046 & 43840 & 95 & Turia & Valencia \\
\hline TU12 & 6720 & 43797 & 550 & Sot & Valencia \\
\hline TU13 & 6535 & 44212 & 605 & Turia & Valencia \\
\hline TU1 & 6943 & 44766 & 1470 & Alfambra & Teruel \\
\hline TU2 & 6703 & 44958 & 1070 & Alfambra & Teruel \\
\hline TU3 & 6635 & 44753 & 930 & Alfambra & Teruel \\
\hline TU5 & 6085 & 44719 & 1530 & Turia & Teruel \\
\hline
\end{tabular}


Appendix.- (Continued).

\begin{tabular}{|c|c|c|c|c|c|}
\hline Site code & X_UTM & Y_UTM & Altitude (m.) & Stream/River & Province \\
\hline TU4 & $6 \overline{627}$ & $4 \overline{4} 268$ & 900 & Arcos & Teruel \\
\hline TU6 & 6317 & 44737 & 1140 & Turia & Teruel \\
\hline TU7 & 6545 & 44550 & 820 & Turia & Teruel \\
\hline TU8 & 6489 & 44259 & 650 & Turia & Cuenca \\
\hline TU9 & 6717 & 43965 & 340 & Turia & Valencia \\
\hline \multicolumn{6}{|c|}{ JÚCARBASIN } \\
\hline JU10 & 5805 & 43504 & 670 & Júcar & Albacete \\
\hline JU11 & 6080 & 43332 & 620 & Júcar & Albacete \\
\hline JU12 & 6338 & 43395 & 515 & Júcar & Albacete \\
\hline JU13 & 6907 & 43489 & 160 & Júcar & Valencia \\
\hline JU15 & 6679 & 43633 & 540 & Magro & Valencia \\
\hline JU16 & 7081 & 43562 & 125 & Magro & Valencia \\
\hline JU17 & 6093 & 44015 & 830 & Guadazaón & Cuenca \\
\hline JU19 & 6876 & 43573 & 290 & Magro & Valencia \\
\hline JU1 & 6244 & 44543 & 1300 & Cabriel & Teruel \\
\hline JU2 & 6141 & 44112 & 850 & Cabriel & Cuenca \\
\hline JU3 & 6434 & 43557 & 390 & Cabriel & Valencia \\
\hline JU4 & 6644 & 43465 & 340 & Cabriel & Valencia \\
\hline JU5 & 6684 & 43361 & 400 & Cantaban & Valencia \\
\hline JU6 & 6048 & 44403 & 1120 & Guadazaón & Cuenca \\
\hline JU7 & 5987 & 44684 & 1300 & Júcar & Cuenca \\
\hline JU8 & 5985 & 44537 & 1200 & Júcar & Cuenca \\
\hline JU9 & 5651 & 44199 & 840 & Júcar & Cuenca \\
\hline \multicolumn{6}{|c|}{ SEGURA BASIN } \\
\hline SE10 & 5972 & 41761 & 650 & Corneros & Murcia \\
\hline SE13 & 6460 & 41635 & 60 & Majada & Murcia \\
\hline SE15 & 6701 & 41023 & 100 & Garruchal & Murcia \\
\hline SE16 & 5901 & 42151 & 780 & Argos & Murcia \\
\hline SE18 & 5488 & 42302 & 720 & Zumeta & Albacete \\
\hline SE1 & 5346 & 42246 & 1020 & Segura & Jaén \\
\hline SE2 & 5345 & 42258 & 1020 & Madera & Jaén \\
\hline SE3 & 5557 & 42219 & 950 & Taibilla & Albacete \\
\hline SE4 & 5492 & 42565 & 1040 & Mundo & Albacete \\
\hline SE5 & 5815 & 42675 & 650 & Mundo & Albacete \\
\hline SE6 & 6175 & 42439 & 330 & Mundo & Albacete \\
\hline SE7 & 5975 & 42104 & 710 & Quipar & Murcia \\
\hline SE8 & 6314 & 42166 & 410 & Perea & Murcia \\
\hline \multicolumn{6}{|c|}{ ALMANZORABASIN } \\
\hline AL1 & 5357 & 41323 & 1000 & Sauco & Almería \\
\hline AL10 & 5539 & 41327 & 600 & Sierro & Almería \\
\hline AL11 & 5533 & 41306 & 760 & Sierro & Almería \\
\hline AL14 & 5690 & 41280 & 560 & Chercos & Almería \\
\hline AL15 & 5666 & 41277 & 760 & Chercos & Almería \\
\hline AL17 & 5919 & 41342 & 180 & Almanzora & Almería \\
\hline AL2 & 5357 & 41323 & 960 & Sauco & Almería \\
\hline AL3 & 5403 & 41335 & 820 & Herrerías & Almería \\
\hline AL4 & 5427 & 41341 & 760 & Almanzora & Almería \\
\hline AL5 & 5493 & 41334 & 690 & Bacares & Almería \\
\hline AL6 & 5500 & 41310 & 800 & Bacares & Almería \\
\hline AL7 & 5493 & 41290 & 920 & Bacares & Almería \\
\hline \multicolumn{6}{|c|}{ AGUAS BASIN } \\
\hline AG1 & 5826 & 41052 & 260 & Aguas & Almería \\
\hline AG2 & 5844 & 41055 & 210 & Aguas & Almería \\
\hline AG3 & 5862 & 41073 & 180 & Aguas & Almería \\
\hline AG5 & 5950 & 41115 & 60 & Aguas & Almería \\
\hline AG7 & 5883 & 41135 & 210 & Jauto & Almería \\
\hline
\end{tabular}


Appendix.- (Continued).

\begin{tabular}{llllll}
\hline Site code & X_UTM & Y_UTM & Altitude (m.) & Stream/River & Province \\
\hline ADRABASIN & 5001 & 40701 & 80 & Adra & Almería \\
AD1 & 4974 & 40862 & 370 & Adra & Almería \\
AD2 & 4984 & 40762 & 200 & Adra & Almería \\
AD3 & 4990 & 40935 & 680 & Adra & Almería \\
AD4 & 4982 & 41038 & 1820 & Adra & Almería \\
AD5 & & & & & \\
\hline GUADALFEOBASIN & 4549 & 40786 & 160 & Guadalfeo & Granada \\
GU10 & 4690 & 40943 & 1540 & Poqueira & Granada \\
GU11 & 4677 & 40887 & 1000 & Poqueira & Granada \\
GU12 & 4674 & 40851 & 500 & Poqueira & Granada \\
GU13 & 4540 & 40938 & 1100 & Torrente & Granada \\
GU14 & 4774 & 40967 & 1540 & Trevélez & Granada \\
GU15 & 4674 & 40841 & 500 & Guadalfeo & Granada \\
GU16 & 4636 & 40916 & 1860 & Chico & Granada \\
GU1 & 4541 & 40989 & 1300 & Dúrcal & Granada \\
GU2 & 4489 & 40949 & 760 & Dúrcal & Granada \\
GU3 & 4487 & 40878 & 500 & Dúrcal & Granada \\
GU4 & 4832 & 40931 & 1350 & Guadalfeo & Granada \\
GU5 & 4814 & 40856 & 860 & Guadalfeo & Granada \\
GU6 & 4733 & 40834 & 540 & Guadalfeo & Granada \\
GU7 & 4657 & 40828 & 340 & Guadalfeo & Granada \\
GU8 & 4596 & 40815 & 220 & Guadalfeo & Granada \\
GU9 & & & & & \\
\hline GUADALQUIVIR BASIN & 2181 & 41586 & 60 & Guadiamar & Sevilla \\
GE & & & &
\end{tabular}

